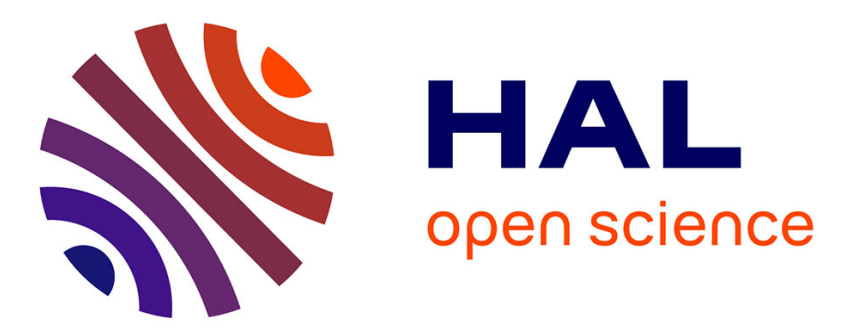

\title{
Tectono-Sedimentary Analysis of the Hyperextended Liwan Sag Basin (Midnorthern Margin of the South China Sea)
}

\author{
C. Zhang, M. Su, X. Pang, J. Zheng, B. Liu, Z. Sun, G. Manatschal
}

\section{- To cite this version:}

C. Zhang, M. Su, X. Pang, J. Zheng, B. Liu, et al.. Tectono-Sedimentary Analysis of the Hyperextended Liwan Sag Basin (Midnorthern Margin of the South China Sea). Tectonics, 2019, 38 (2), pp.470-491. 10.1029/2018TC005063 . hal-03102487

\section{HAL Id: hal-03102487 \\ https://hal.science/hal-03102487}

Submitted on 1 Sep 2021

HAL is a multi-disciplinary open access archive for the deposit and dissemination of scientific research documents, whether they are published or not. The documents may come from teaching and research institutions in France or abroad, or from public or private research centers.
L'archive ouverte pluridisciplinaire HAL, est destinée au dépôt et à la diffusion de documents scientifiques de niveau recherche, publiés ou non, émanant des établissements d'enseignement et de recherche français ou étrangers, des laboratoires publics ou privés.

$$
\text { Copyright }
$$




\section{Tectonics}

\section{RESEARCH ARTICLE 10.1029/2018TC005063 \\ Key Points: \\ - The interaction between tectonic \\ Tectono-Sedimentary Analysis of the Hyperextended Liwan Sag Basin (Midnorthern Margin of the South China Sea)} extension, gravitational and sedimentary processes has been investigated in the hyper-extended Liwan sag

- The tectono-sedimentary evolution has been reconstructed by analyzing the sedimentary sequences and syn-depositional deformation

- The Liwan sag overlying hyper-extended crust records a complex rift to drift evolution including the formation of dome-shaped structures

Supporting Information:

- Supporting Information S1

- Figure S1

- Figure S2

- Figure S3

- Figure S4

- Figure S5

Correspondence to:

M. Su,

suming3@mail.sysu.edu.cn

Citation:

Zhang, C., Su, M., Pang, X., Zheng, J., Liu, B., Sun, Z., \& Manatschal, G. (2019). Tectono-sedimentary analysis of the hyperextended Liwan sag basin (midnorthern margin of the South China Sea). Tectonics, 38, 470-491. https://doi.org/10.1029/2018TC005063

Received 19 MAR 2018

Accepted 8 JAN 2019

Accepted article online 11 JAN 2019

Published online 1 FEB 2019

(C)2019. American Geophysical Union. All Rights Reserved.

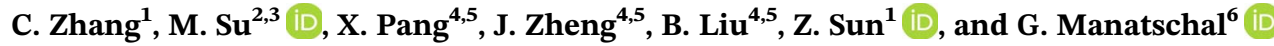 \\ ${ }^{1}$ CAS Key Laboratory of Ocean and Marginal Sea Geology, South China Sea Institute of Oceanology, Guangzhou, China, \\ ${ }^{2}$ School of Marine Sciences, Sun Yat-sen University, Zhuhai, China, ${ }^{3}$ Guangdong Provincial Key Laboratory of Marine \\ Resources and Coastal Engineering, Zhuhai, China, ${ }^{4} \mathrm{CNOOC}$ Ltd.-Shenzhen, Shenzhen, China, ${ }^{5} \mathrm{CNOOC}$ Ltd.- \\ Deepwater, Shenzhen, China, ${ }^{6}$ IPGS/CNRS, Université de Strasbourg, Strasbourg Cedex, France
}

\begin{abstract}
Although hyperextended rifted margins have been the focus of many recent studies, the potential interaction between tectonic deformation and sedimentation during extreme crustal thinning is poorly understood. In this study, we aim to explore the tectono-sedimentary evolution during final rifting and lithospheric breakup in the hyperextended Liwan sag basin. We demonstrate the presence of an oceanward inclined shale sequence, which acts as a decoupling level separating a subshale from a suprashale layer. The suprashale layer is characterized by progradational deltaic facies with a high sediment supply to the north and basal facies farther south. Extensional faults together with local gravitational structures are syndepositional and formed during hyperextension. The shale is observed to overlie a highly attenuated basement comprising high-reflective sequences that may correspond to meta-sediments. We propose a new model to explain the interaction of tectonic deformation, gravity sliding, and sedimentation. A first stage includes the crustal necking that goes along with the deposition of synrift deltaic sequences decoupled above prodelta shales. During hyperextension, a high sediment supply is linked to migration of depocenters and extension oceanward. The prodelta shale layer acts as the main decoupling level, gravity sliding affects synhyperextensional sediments, and dome-shape structures start to form. During a third stage, deformation migrates outboard, while formation of dome structures continues in the Liwan sag basin. Although the process controlling these dome-shape structures remains unclear, a magmatic origin is likely. Diffuse deformation related to differential compaction and minor magmatic additions continued to affect the margin after the onset of seafloor spreading.
\end{abstract}

\section{Introduction}

Although sag basins have been reported from many hyperextended rifted margins worldwide, at present their tectono-sedimentary evolution has been little investigated. This is mainly because most sag basins at hyperextended rifted margins are below thick postrift sedimentary sequences and are often masked by salt (Hudec \& Jackson, 2004; Jammes et al., 2010). In the past decades there has been an increasing interest in understanding distal rifted margins, that is, the processes and the evolution of rift systems developing into seafloor spreading (e.g., Huismans \& Beaumont, 2011; Larsen et al., 2018a; Reston \& McDermott, 2011; Whitmarsh et al., 2001). At present, however, except from industry data, there are only a few high-quality seismic and drill hole data sets from these distal domains that are accessible to the scientific community. The Liwan sag basin is one of these exceptions from which high-resolution 3-D seismic data are available and, due to drilling, the main stratigraphic sequences have been dated and correlated across the margin. This information enables a reconstruction of the evolution of this basin and understanding of the processes controlling its formation. For the Liwan sag basin, key questions are how deformation, including tectonic and gravitational processes, interacts with sedimentation and subsidence during final rifting and the onset of seafloor spreading and how the observed sedimentary architecture of this sag basin can help to better understand the evolution of the midnorthern margin of the South China Sea (SCS).

The Liwan sag basin is made of deformed syntectonic sedimentary sequences. Deformed synrift sequences are commonly observed along distal rifted margins, whereby two basic types of deformation can be described: one is driven by tectonic stresses (e.g., Gillard et al., 2015; Lister et al., 1991; Osmundsen \& Ebbing, 2008; Péron-Pinvidic et al., 2007), while the other is the result of gravitational forces. Tectonic 
deformation occurs during the so-called synrift stage, that is, while the curst is thinning and extending. Gravitational-induced deformation commonly occurs during the postrift stage, while the margin is thermally subsiding and thick sedimentary sequences fill the available accommodation space. Gravitational deformation at rifted margins is classically linked to either salt or shale levels as documented along Atlantic type margins (West African-east South American margins), the Gulf of Mexico, the Red Sea, and many other examples (for review see Morley et al., 2011). These classic examples consist of thin-skinned systems that are, in most examples, postrift (e.g., Duval et al., 1992; Rowan et al., 2004; Spathopoulos, 1996). Synrift, gravity-driven deformation has been observed along the northern West African margin (Morocco, Mauritania, Senegal; e.g., Tari et al., 2003), the Nova Scotia margin (Deptuck et al., 2009; Ings \& Shimeld, 2006; Wade \& MacLean, 1990), and the northern Gulf of Mexico (e.g., Peel et al., 1995). In these examples, the interaction of tectonic and gravitational deformation results in synrift structural complexity. However, it remains unclear how to distinguish between tectonic and gravitational-induced deformation in the presence of strong decoupling layers. Espurt et al. (2009) and Jammes et al. (2010) showed that the two processes can interact and occur simultaneously. In this study we discuss the links among sedimentation, tectonic deformation, and gravitational deformation during extreme crustal thinning in the Liwan sag basin.

The aim of this paper is to (1) examine, describe, and interpret synrift sedimentary sequences and their syndepositional deformation history (tectonic and gravitational) recorded in a high-resolution 3-D seismic data set and (2) link the tectono-sedimentary evolution observed in the sag basin to the first-order isostatic and kinematic evolution of the whole rifted margin. In this paper we interpret a new 3-D seismic data set of the Liwan sag basin (Ji et al., 2014; Miao et al., 2013) that provides new, compelling information on the evolution of the distal domain of the midnorthern margin of the SCS.

\section{Geological Setting}

The SCS is one of the largest marginal seas along the western Pacific margin. Its evolution has been heavily influenced by three major plates, the Pacific, the Eurasian, and the Indian-Australian plates. The northern SCS developed in a transitional context from an active to a passive margin. Extension in this area has been interpreted to have started at $65 \pm 10 \mathrm{Ma}$ in the Late Cretaceous-Early Paleocene (Hinz \& Schlüter, 1985; Holloway, 1982). This extension overprinted and postdated the subduction of the Meso-Tethys and PaleoPacific underneath Eurasia during the Late Jurassic to Early Cretaceous (Zhou et al., 2006). In this geological setting, a series of rift basins were created in the northern margin of the future SCS. The Pear River Mouth Basin (PRMB) is located in the midnorthern margin of the SCS (Figure 1) and will be the main focus of this paper.

The PRMB is a Mesozoic-Cenozoic petroliferous basin with a total area of $200,000 \mathrm{~km}^{2}$. The sedimentary architecture of the PRMB can be subdivided in two parts: a lower part made of Paleocene-Oligocene sediments that record the crustal stretching history (synextensional) and an upper part made of Neogene to Quaternary sediments that record the postrift thermal subsidence of the basin (Huang et al., 2005; Ru \& Pigott, 1986). These two sequences are separated by the breakup unconformity T70 in the PRMB. T70 is interpreted to define the moment when oceanic crust first formed at the midnorthern margin segment of the SCS. It corresponds to magnetic anomaly $\mathrm{C} 11 \mathrm{n}$, which is dated at $32 \mathrm{Ma}$ (early Oligocene) according to the magnetic time scale of Patriat (1987; see also Briais et al., 1993; Taylor \& Hayes, 1983). Several episodes of continental extension preceded seafloor spreading in the PRMB, including the Shenhu Event (onset of rifting dated as early Paleocene; Pang et al., 2007), and the first and second episodes of rifting, corresponding to the Zhuqiong Events marked by major unconformities T90 and T80, respectively. The T90 boundary has not been recognized in the PRMB (Pang et al., 2007).

In this study, the main focus will be on the Liwan sag basin. It lies between the Yunli Low Uplift and the Outer Marginal High (OMH) that separates the Liwan sag basin from the oceanic crust (Figure 1). The maximum sediment thickness reaches up to $8 \mathrm{~km}$ in the center of the Liwan sag basin. The crust under the center of the basin has been strongly extended to a thickness of $<9 \mathrm{~km}$ and locally even to $<5 \mathrm{~km}$ (Gao et al., 2015; Yan et al., 2001). Ji et al. (2014) identified extensional faults and diapirs in the Liwan sag and suggested that these structures formed coeval to the opening of the northwest subbasin of the SCS. The area south of the Liwan sag basin has been drilled during International Ocean Discovery Program (IODP) Legs 367/368. The basin has been imaged by two-dimensional (2-D) long-cable and three- dimensional (3-D) reflection 

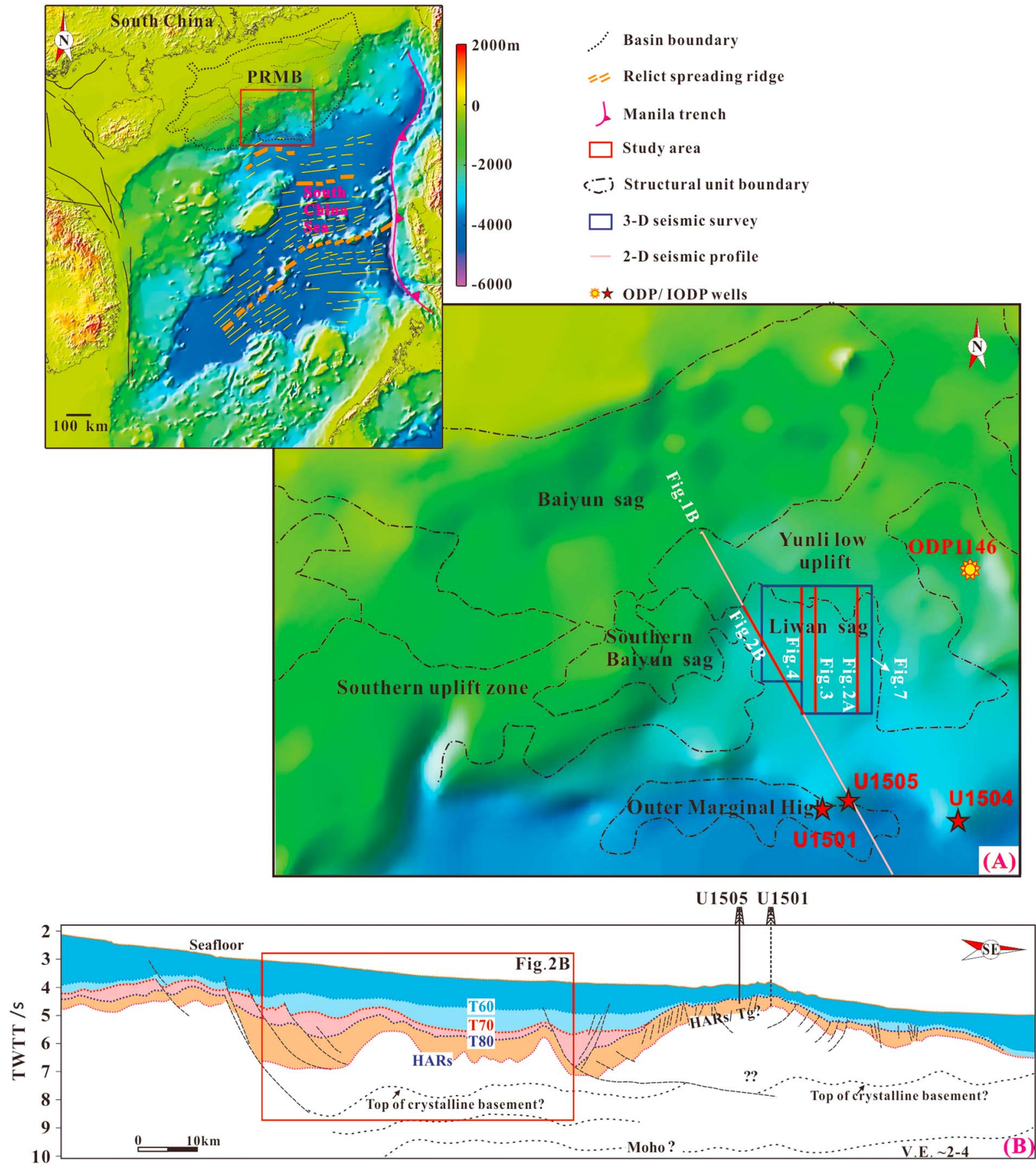

Figure 1. (a) Bathymetric map of the Pearl River Mouth Basin with the structural divisions, Ocean Drilling Program/International Ocean Discovery Program (ODP/IODP) drill holes and seismic survey presented in this paper. The dot-dashed black line marks the boundaries of structural units; the blue box indicates the study area, as well as the location of the 3-D seismic survey; the pink line corresponds to a long cable seismic profile shown in Figure 1b. The upper left inset shows the location of the Pear River Mouth Basin (PRMB) in the South China Sea. (b) Interpreted seismic reflection profile showing the large-scale structural configuration and the main sedimentary sequences used in this paper. Note the major rift and deep structures in the Liwan sag basin. Abbreviation used in this and other seismic cross sections: HARs, high-amplitude reflectors; V.E., vertical exaggeration.

seismic surveys. In the past, research addressed key issues such as the sedimentary system (Liao et al., 2016; Liu et al., 2016), the nature and structure of the deep crust (Gao et al., 2015; Yan et al., 2001; Zhou et al., 2006), and the synrift extensional structures (Ji et al., 2014; Xie et al., 2014). However, a more detailed description of the tectono-sedimentary architecture of the Liwan sag basin and a discussion of its 
evolution and mechanism in the framework of the whole margin is still missing and will be the aim of this paper.

\section{Data and Methods}

The wealth of data sets, including 3-D seismic data and wells, make the SCS and the Liwan sag basin in particular an ideal place to map and correlate deformation and sedimentary structures over a large distance. The multichannel seismic data set used in our study was acquired by the China National Offshore Oil Corporation (CNOOC) from 2002 to 2004 with 576 channels ( 200-7,400-m offset). The long 2-D profiles were collected by a 7.5-km long cable. The data were sampled at $2 \mathrm{~ms}$ and recorded up to $10 \mathrm{~s}$ (two-way travel time, hereafter TWTT; Figure 1b). The 2-D seismic profile presented in this study runs across the Liwan sag basin and extends over oceanic crust. In places, deep crustal reflections above the Moho are visible, although the interpreted Moho remains a matter of debate. The 3-D seismic data cover the major Liwan sag basin, with a total surface area of 1,600 $\mathrm{km}^{2}$ (Figure 1a). Both 2-D and 3-D seismic profiles have uniform acquisition and processing parameters, and the trace interval is $12.5 \mathrm{~m}$. These data are the basis for this paper.

Since 1999, four drilling expeditions (Ocean Drilling Program [ODP] Leg 184 and IODP Legs 349, 367, and 368) have been conducted at the northern margin of the SCS. Two IODP Sites 1501 and 1505 are located over the $\mathrm{OMH}$, which forms the oceanward boundary of the Liwan sag basin (Figure 1). The preliminary timedepth correlation and age model obtained from the two sites over the OMH are coherent with our interpretation (Jian et al., 2018; Larsen et al., 2018b), so the sequence boundaries T60 and T80 are well constrained on the seismic lines. Thus, in addition to unconformity T70, T80 is a major unconformity, corresponding to a regional tectonic event (second episode of Zhuqiong extension).

This study is mainly based on the description and interpretation of a new 3-D seismic data set imaging the sedimentary infill and deformation of the Liwan sag basin and regional 2-D seismic lines imaging the underlying crustal structure of the whole margin. Based on the sequence division boundaries T80, T70, and T60 drilled in wells and described in previous studies, in this paper we further define our own seismicsedimentary units below the T80 boundary. The definition of the seismic-sedimentary units is based on the observation of the seismic reflection geometry, the seismic stacking patterns, and the seismic facies made on numerous seismic lines of the 3-D seismic survey. Such units cannot be correlated directly with the stratigraphic levels in the proximal margin. Thus, we cannot date the seismic-sedimentary units directly, but we can at least define time lines in the southern distal PRMB.

\section{Results}

\subsection{Basement and HARs}

Due to the low seismic resolution, the lack of deep wells in the basin, and the hyperextended nature of the Liwan sag basin, the nature of the basin's basement flooring is unconstrained. Although several competing models made clear predictions about the nature of the basement (Gao et al., 2015; Miao et al., 2013; Zhou et al., 2018), at present none of these models have been tested by drilling. At present, there is little consensus among different interpretations. However, the high-resolution 3-D seismic data acquired recently and used in this study provide an excellent chance to analyze the structures of the crust flooring the Liwan sag basin. In the 3-D seismic survey (Figure 2), High-amplitude reflectors (HARs), located from about 3.7 to $6.6 \mathrm{~s}$ (TWTT) and occurring throughout the Liwan sag basin, are the most prominent structures. These HARs exhibit irregular undulations and predominately dip oceanward.

As shown in Figure 2, the HARs subdivide two first-order seismic sequences, referred to as the sub-HARs and the supra-HARs (Figure 2). The sub-HAR sequence is characterized by low-frequency, low-amplitude reflections, which can be subdivided into two packages. The upper one consists of moderate continuous reflections that are parallel to the undulating HARs. The bottom one consists of low-frequency reflections, in places showing a variation from distinctly oblique to parallel with the overlying HARs. Farther oceanward it appears that these reflections converge and finally merge with the HARs. In contrast, the supra-HAR sequence is characterized by alternating high-frequency transparent and high- to moderate-amplitude reflections. The deformation structures observed in the supra-HAR sequence, characterized by abundant normal faults and domes, are strikingly different from those observed in the sub-HARs sequence. 

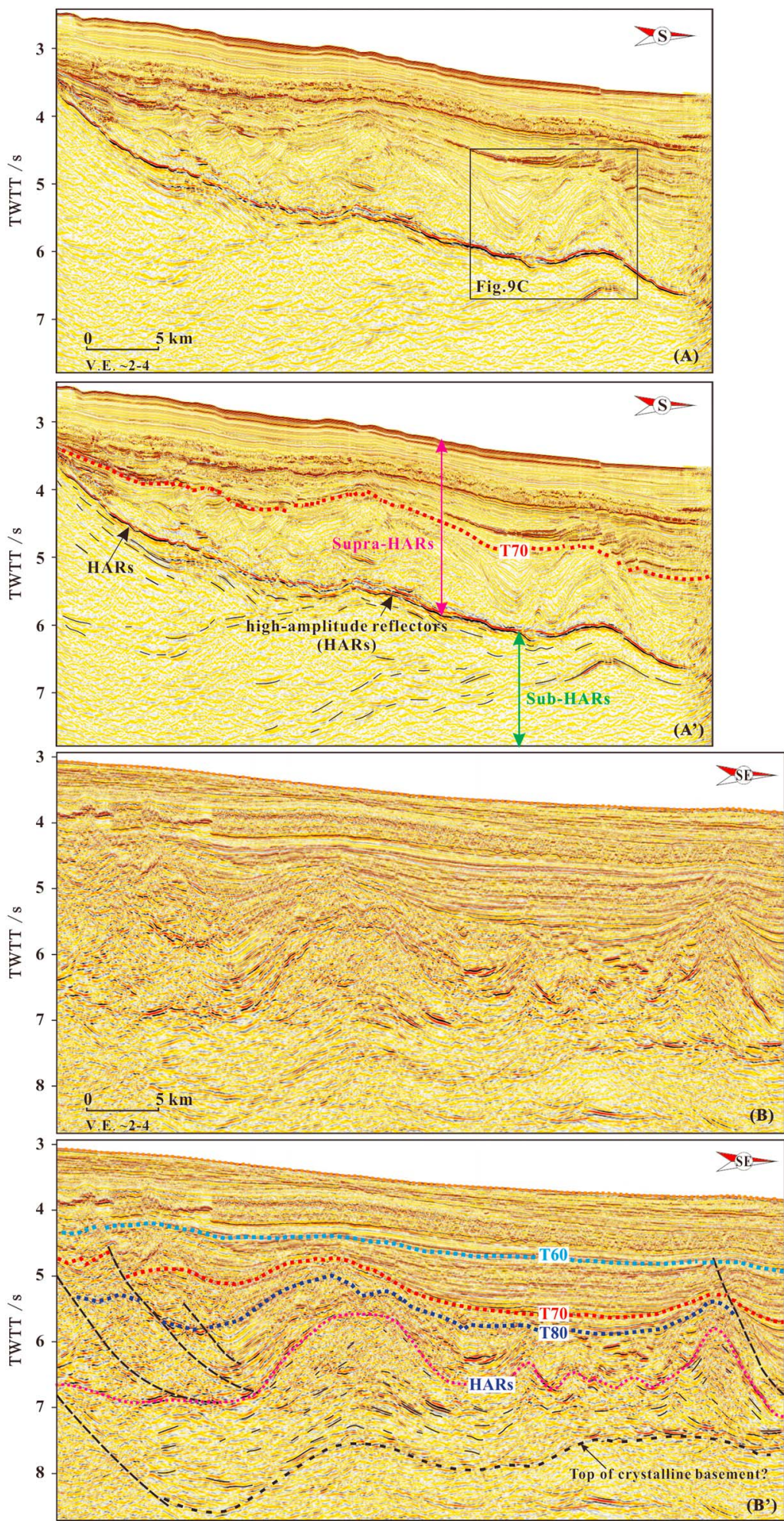

Figure 2. (a and a') Interpretation of time migrated seismic line showing the structural configuration of the Liwan sag basin (for location see Figure 1). High-amplitude reflectors (HARs) divide the whole section into two sequences showing strikingly different reflections and structures. Note that the bottom sub-HARs consist of oblique reflectors underlying strong reflections that are parallel to the undulating HARs. ( $b$ and $b^{\prime}$ ) Part of a long cable time migrated seismic line. Interpretation shows more details below HARs and potential top of crystalline basement. The HARs were mapped though the 3-D seismic survey and the HARs in (b) correspond to a mapped surface. Note the bottom sub-HARs showing well-layered reflections reaching to more than 7-s (TWTT) depth. 
Considering that the upper packages in the sub-HAR sequence is well laminated and continuous, a sedimentary rather than a crystalline nature of the basement is considered for this unit. The deeper package may consist of hyperextended crystalline basement (Figure 2b). In contrast, the seismic architecture changes strikingly in the overlying sequence, especially between the HARs and T70, the latter corresponding to onset of seafloor spreading farther outboard. Indeed, the seismic images show that this sequence experienced complicated deformation in response to the development of the rifted margin preceding lithospheric breakup in the SCS. Whatever the interpretation of the HARs is, it represents a key structure with respect to the tectonosedimentary evolution of the Liwan sag basin.

\subsection{Sedimentary Units in the Supra-HAR Sequence}

In the following paragraphs, seven seismic-sedimentary units between HARs and T60 are defined and described (Figure 3). The main characteristics of these seismic-sedimentary units are described below in terms of boundaries, geometry, seismic architecture, and structures. We will discuss, where appropriate, the age of the units and the location of depocenters, referred to as the location of the thickest sediments in the different units.

\subsubsection{Sedimentary Unit 1}

The basal seismic-sedimentary Unit 1 (U1) corresponds to the first identifiable unit, of which the lower limit is the deep-seated, undulating HARs. The upper limit is marked by a low- to moderate-amplitude, continuous reflector. U1 comprises subparallel internal reflections in the upper part to low-amplitude chaotic reflections in the lower part (Figures 3 and 4). In the proximal part, U1 is affected by several intraunit normal faults, which dip oceanward and sole out on the low-amplitude reflectors, which overlie HARs and show thickening in the footwalls of normal faults. These faults that create small offsets in the U1 are inferred to have been active during the deposition of U1. Affected by such syndepositional faults, the thickness of U1 reaches its maximum in the most proximal Liwan sag basin. The low-amplitude reflectors are not limited in U1 but comprise the sediments from overlying units (Figures 3 and 4), which makes it difficult to distinguish U1 from the overlying units and to define the oceanward extent of this unit. As shown in Figures 3 and 4 , no direct data constrain the age of $U 1$.

\subsubsection{Sedimentary Unit 2}

A thick, well-stratified package downlapping toward the top of U1 is referred to as a younger seismicsedimentary Unit 2 (U2) in the proximal part. In the central and distal parts, sediments of U2 merging with $\mathrm{U} 1$ comprise the low-amplitude reflectors in the bottom. The top of $\mathrm{U} 2$ is confined by a moderate-amplitude, continuous reflector. U2 is characterized by variable amplitude and continuity in seismic character (Figures 3 and 4). In the proximal part, it appears as transparent, discontinuous reflections, whereas in the central and distal parts, U2 has moderate- to high-amplitude, moderate to fairly continuous reflections. $\mathrm{U} 2$ is marked by a first prominent, progradational sequence (Figure 5a). A typically stratal architecture is visible, that is, with an ascending trajectory, oceanward foreset increasing angle and offlap. The foreset displaying a rollback anticline is likely associated with a dip change in the fault (Figure 3). U2 is affected by dome-shaped structures (Figure 4), consequently resulting in the postdepositional uplift and rotation of the progradational sequence. In the proximal part, U2 is affected by intraunit normal faults with small offsets. These faults root at the low-amplitude reflectors overlying HARs. The depocenter of U2 coincides with a progradational sequence.

4.2.3. Sedimentary Unit 3

Unit 3 (U3) conformably overlies U2. Its top is located at the base of a low-amplitude reflector, which in places is unconformably separated along the unconformities T80 or/and T70 from the overlying sediments. U3 appears well stratified with parallel reflectors with moderate amplitude. Like U1 and U2, U3 is affected by intraunit normal faults. These faults sole either in U2 in the proximal part of Figure 3 or onto the lowamplitude reflectors in the central part of Figure 4. They are inferred to be active during the deposition of U3, whereas those soling in U2 and U3 in the proximal part of Figure 4 were active during deposition of U4 and U5. Farther southward, U3 is, together with U1 and U2, involved in an anticline structure, the crest of which was uplifted, reaching a height of more than 2-s TWTT above the basal HARs. At the crest of this structure, U3 underwent substantial erosion, as marked by the unconformities T80 or T70. In the two limbs, U3 shows parallel reflectors that are conformable with the antiformal geometry (Figure 5b). No thinning toward the crest is visible. It is notable that in the southern limb of the dome, U3 is affected by a normal fault, which is separated from younger sediments (Figure 4). The fault offset reaches up to 1-s TWTT. The 

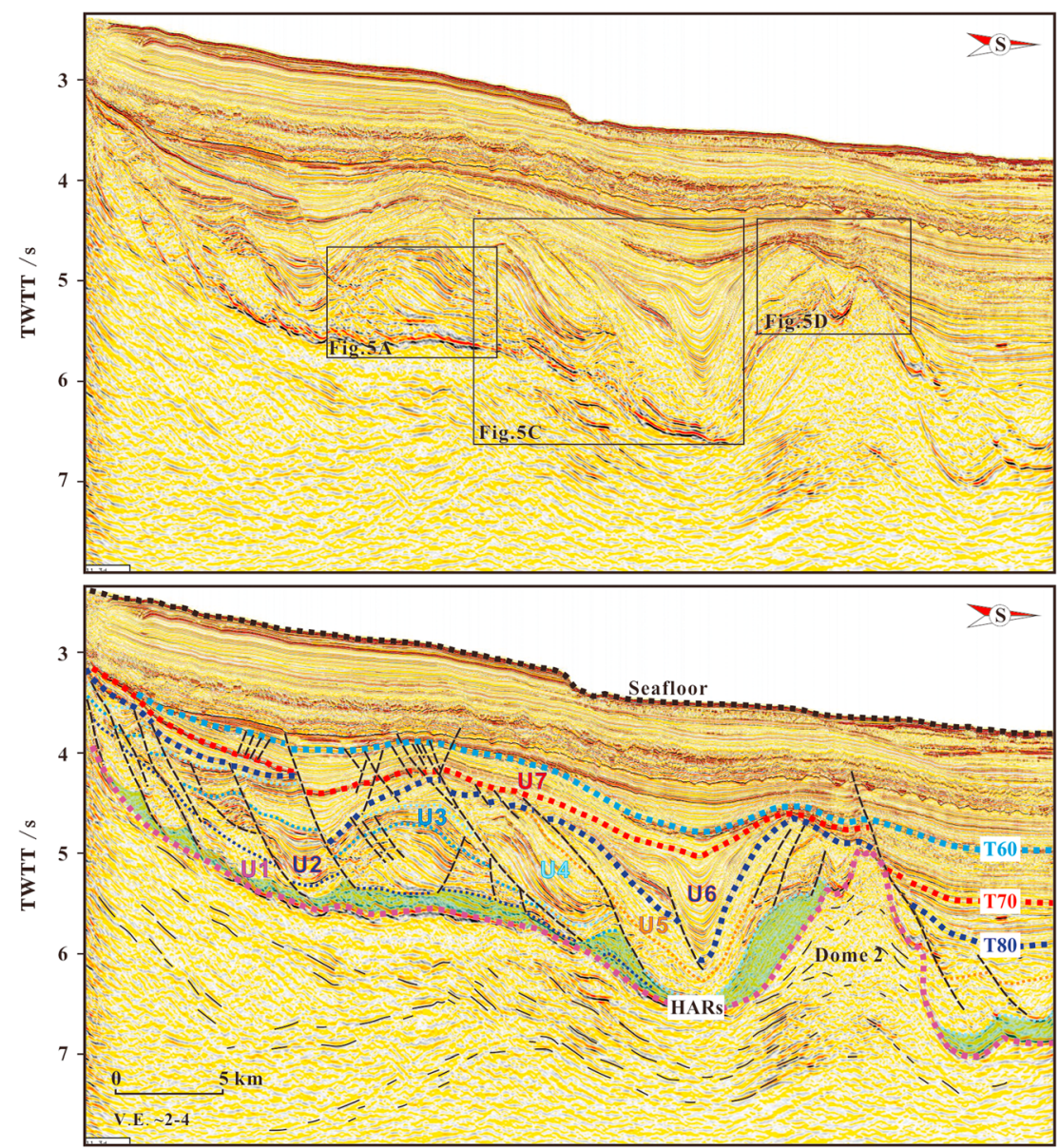

Figure 3. Seismic line and interpretation, showing the structures, boundaries, and characteristics of the seven seismicsedimentary units (for location see Figure 1). Note that the normal faults sole out onto the low-amplitude reflectors thickening in the footwalls of normal faults and overlying high-amplitude reflectors (HARs). All faults terminate in the supra-HARs. Dome 2 displays almost a symmetric structure; the reflectors in the crest of dome 2 exhibit a pull-up geometry.

thickness of U3 appears relatively thin and constant compared with that of U2. Neither the deposition age nor the unequivocal sedimentary extent of $\mathrm{U} 3$ can be defined.

\subsubsection{Sedimentary Unit 4}

$\mathrm{U} 3$ is conformably overlain by a younger seismic-sedimentary unit, referred to as U4. The upper limit of U4 is defined by the base of U5; however, in the proximal part, U4 and U5 were substantially eroded. As a consequence, U4 is directly topped by the continuous erosional surface T80, exhibiting high-amplitude, fairly continuous reflections that mark intense truncations and form a significant hiatus (Figure 5b). Occasionally, its top is defined by the upward change to the transparent reflectors (Figures 3 and 4). U4 has a continuous seismic character with variable amplitudes. In the southern limb of the dome, U4 shows distinctly different depositional geometries from U3. Whereas U3 shows constant thickness and parallel reflections, U4 is characterized by sigmoidal shapes comprising a high-angle progradation system with well-defined topsets, foresets, and downlapping sequences onto the base of U4. In the proximal part, U4 and its eroded top surface T80 are affected by several normal faults with small offsets. In the central part, U4 has been affected by dome-shaped structures as well as U1-U3. Farther southward, a large-offset normal fault affecting the progradational pattern of U4, roots into the HARs. The basal sediments of U4 display downlaps toward the fault planes (Figure 5c). Generally, the depocenter of U4 is located at the southern limb of dome 1. In the most distal part, several faults cut through the HARs and terminate in the upper package of the sub-HARs. 

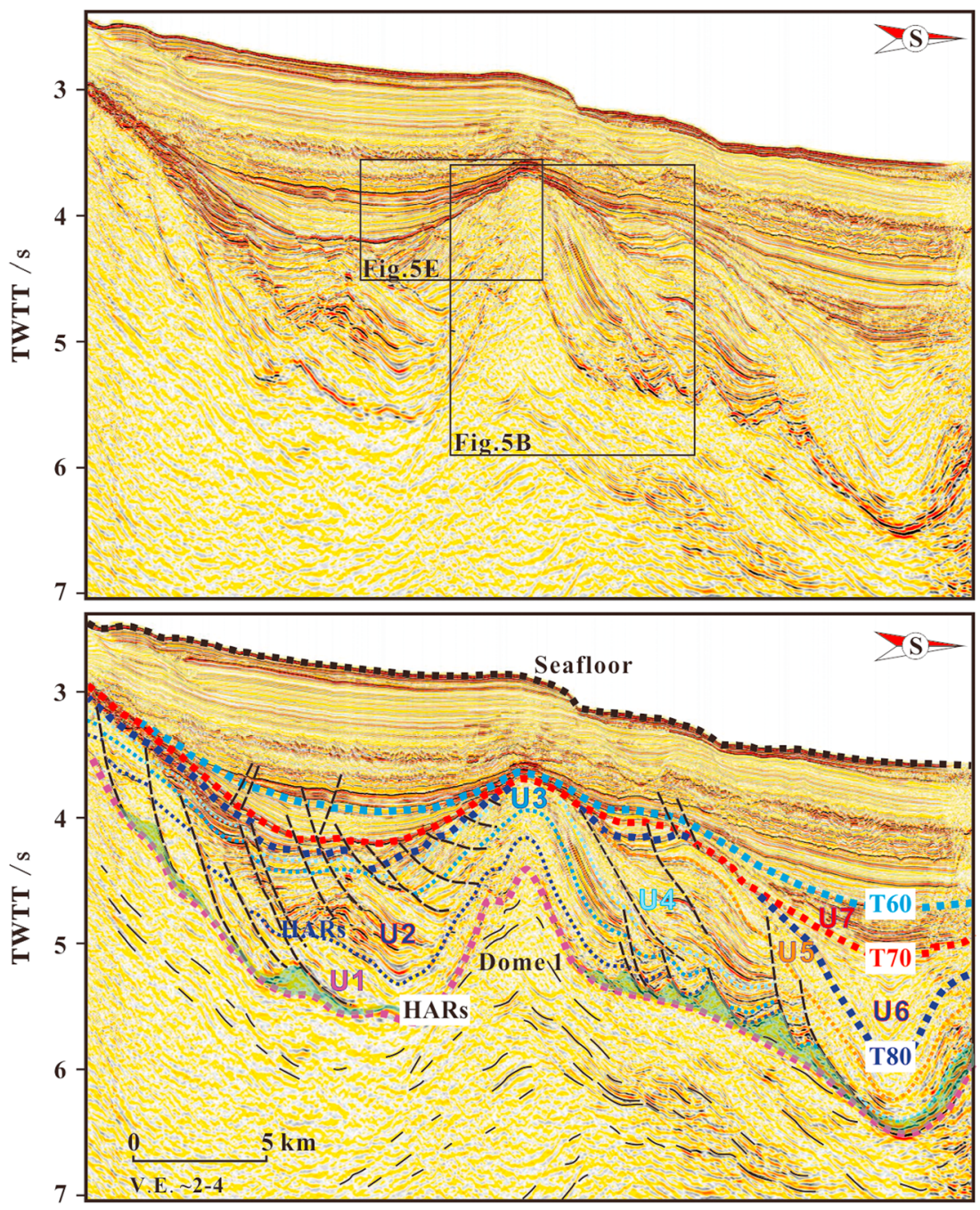

Figure 4. Seismic line and interpretation, showing the structures, boundaries, and characteristics of the seven seismic-sedimentary units (for location see Figure 1). Note the occurrence of normal faults in the proximal part soling out either onto the high-amplitude reflectors (HARs) or onto the low-amplitude reflectors. The location of dome 1 correlates with an antiform in the sub-HARs.

\subsubsection{Sedimentary Unit 5}

The boundary between the seismic-sedimentary Unit 5 (U5) and U4 is evident as shown in the southern limb of the dome (Figure 5c), where it is unconformable. Compared to U4, U5 appears less stratified with generally transparent internal reflectors, which show a little sense of progradational geometry downlapping onto the base of U5 (Figure 3). U5 is capped by the unconformity T80, which has substantially truncated the underlying sediments from U3 to U5. As a consequence, U5 has been totally eroded in the northern Liwan sag basin. U5 in the southern limb of the dome is affected by a high-angle normal fault, which roots into the low-amplitude reflectors. Like U4, the deposition of U5 is influenced by the occurrence of this fault, exhibiting an oceanward tilting along with the fault plane and thickening into the hanging wall, corresponding to the depocenter of U5. In the distal part, U5 is involved with the underlying units in another new domeshaped structure. In the crest of this structure, a significant truncation corresponding to the T80 unconformity seals the faults crosscutting the HARs.

\subsubsection{Sedimentary Unit 6 (T80-T70)}

Unlike the units described above, sedimentary Unit 6 (U6) is widespread in the Liwan sag basin (Figures 3 and 4). Its base is limited by T80 and its top by T70, showing prominent reflectors with higher amplitude than the reflections of U6. Significant erosional truncations of U6 caused by T70 can be observed 


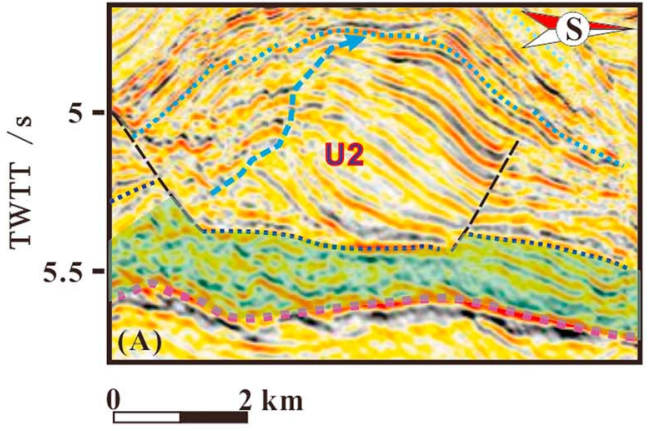

$\rightarrow$ Onlapping

م) Truncation

$\zeta$ Downlapping

Variation of trajectory

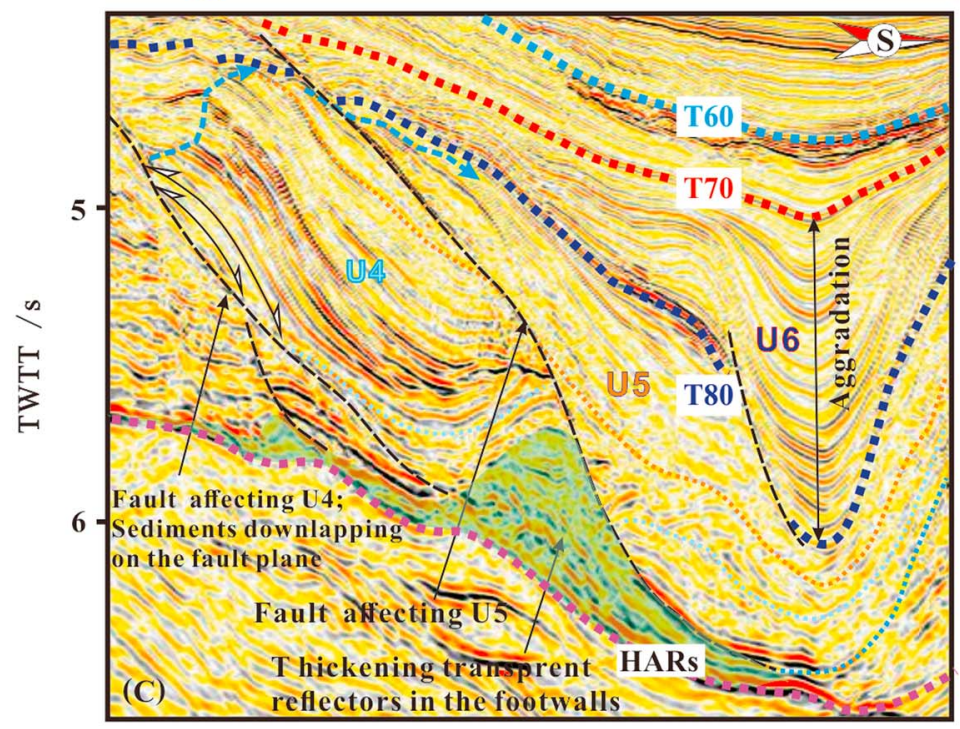

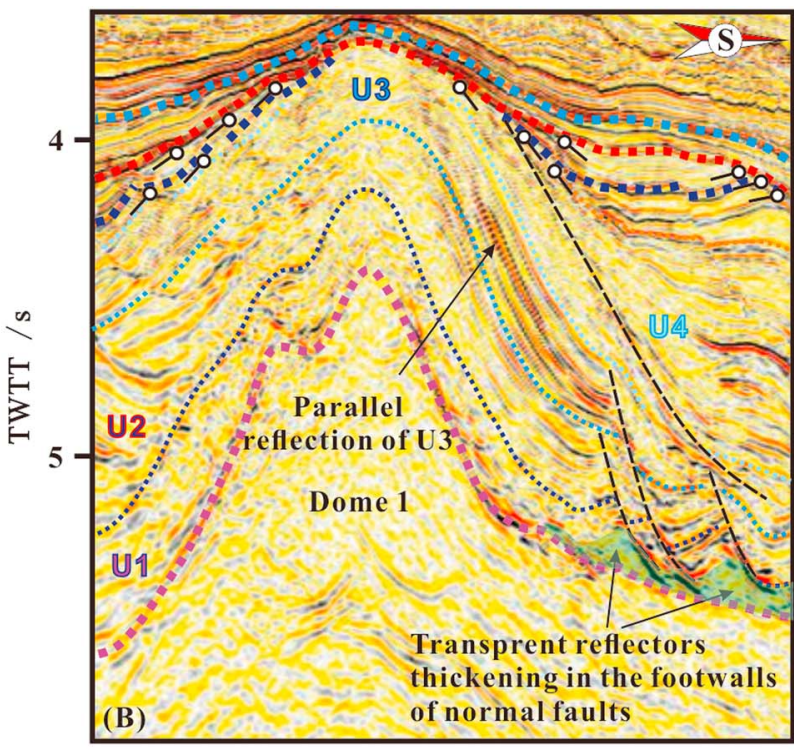
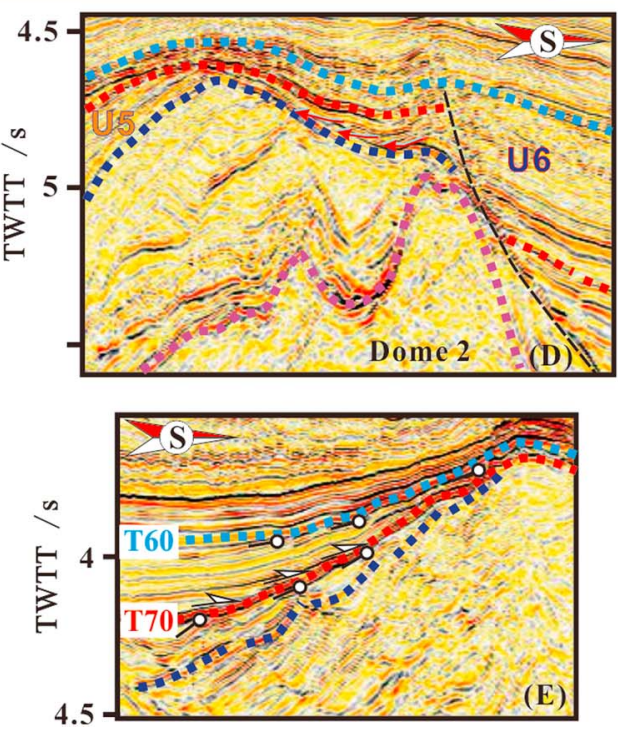

Figure 5. Zooms of seismic lines shown in Figures 3 and 4 showing the major unconformities and deformation/depositional geometries and structures. (a) The prominently progradational sequence and the ascending trajectory associated with U2; (b) U3 with parallel reflection shows conformable geometry with the underlying antiform. U3 is erosionally truncated by the surface T80 and T70 at the crest of the dome 1, as well as U4. Low-amplitude reflectors overlying high-amplitude reflectors (HARs) thicken in the footwalls of normal faults. (c) Both U5 and sigmoid-shaped U4 comprise progradational sequences. Note that U4 and U5 display a high-angle ascending trajectory and slightly descending trajectory, respectively. U6 displays an aggradational geometry. Fault affected U4 was downlapped by the basal sediments of U4. The faults affecting U4 and U5 both root into the low-amplitude reflectors. (d) Erosional truncations caused by the T80 boundary at the crest of dome 2. The basal sediments of U6 onlap toward the crest of dome 2. (e) Erosional truncations caused by T70 and T60. Note the basal sediments of U7 downlap toward the crest of the dome. For locations see Figures 3 and 4.

throughout the basin except in the southernmost part (Figure 3), indicating a widespread hiatus during the early to late Oligocene. Locally, the interface T70 exhibits unconformable contacts with the underlying interface T80. U6 is composed of continuous and low- to moderate-amplitude reflectors. Several normal faults affecting U6 seem to create variable offsets, with the maximum reaching up to 0.7-s TWTT. This fault with the largest offset correspondingly controls the sedimentary wedge of U6 in the hanging wall. In the distal part, two dome-shaped structures confine a small isolated syncline filled by U6, which presents a predominantly aggradational stacking pattern with prominent downlapping reflections toward both limbs, marking the main depocenter of U6. The thickness of U6 is greatly variable, as it is affected by syndepositional normal faults and dome-shaped structures. Defined by two regional unconformities, U6 is inferred to be deposited during the late Eocene to early Oligocene. 


\subsubsection{Sedimentary Unit 7 (T70-T60)}

Seismic-sedimentary Unit 7 (U7) lies on a major unconformity surface T70 above U6, capped by a highamplitude, fairly continuous reflector correlated to the erosive boundary T60. U7 corresponds to a widely distributed unit in the Liwan sag basin. It consists of continuous reflectors, with a few prominent reflections in its lower distal part. The reflections with moderate amplitude in the proximal part are predominantly subhorizontal, draping the underlying U6. Those with high amplitude in the distal part show onlapping toward the underlying structural highs. Most structures (faults and domes) are sealed by T60. Some small-scale faults cutting into U7 and the overlying sediments generated little displacement. Since the base of U7 is affected by some normal faults and locally uplifted, the thickness of U7 is greatly variable, and the depocenter appears at the most distal part. U7 was deposited during the late Oligocene and comprises the first postrift sedimentary sequences.

\subsubsection{Summary of Sedimentary Units}

Seismic observations allowed us to define seven seismic-sedimentary units (U1 to U7) based on the seismic geometry, the seismic stacking pattern, and the seismic facies made on lines of the 3-D seismic surveys. All units thin oceanward and are juxtaposed at their distal part, leading to difficulty in following and mapping their distal boundaries. Moreover, the intraunit low-amplitude reflectors overlying the HARs make it difficult to define the boundaries of the units. In the proximal part, low-amplitude reflectors are observed at the bottom of U1; in the central and distal part, they comprise sediments from U1 and U2 and even U3. All sedimentary units can be identified on all seismic lines interpreted in this study. Generally, the low-amplitude reflectors are marked by thickening under the faulted blocks. Our interpretation indicates that each unit coincides with a characteristic stacking pattern and distribution. Only the ages of U6 and U7 can be inferred by integrating stratigraphic information from available wells and previous studies. U7 represents the first postrift sedimentary sequence dated from 32 to $23 \mathrm{Ma}$, and U6 was deposited during the last stage of the margin formation. Units beneath U6 record the deposition and deformation related to hyperextension.

On the basis of mapping of these units in the 3-D seismic data, we were able to build a stratigraphic framework and correlate a number of the structures and reflections from north to south across the Liwan sag basin. Moreover, the sedimentary architecture provides insights into the evolution of the basin, which will be used to discuss the tectono-sedimentary evolution of the basin and of the overall margin.

\section{Discussion}

\subsection{Tectono-sedimentary Analysis of U1 to U7}

5.1.1. Stratigraphic Framework and Depocenter Migration

Based on the identification of boundaries between different units, we were able to establish a stratigraphic framework (Figures 6a and 6b). U2 lies conformably on top of U1, whilst U3 lies conformably on top of U2. Post-U3, prominent unconformities can be found, reflecting strong erosional events at the local and/or regional scale of the margin. U3 is topped by unconformity T80, in the crest of the domes by T70, where the overlying U4 has been completely eroded. In the proximal part, U4 is directly capped by the unconformity T80, the truncation of which results in the absence of U5 in the proximal part, whereas in the distal part, U4 is conformably overlain by U5. As a response to the truncation by the major unconformity T80, the remnants of U5 are only preserved oceanward of the anticline structure. U6 is topped by the most important unconformity T70, which not only truncates the underlying U6 and U5 but also truncates the U3 in places. The erosive attitude on the top of U6 can be observed throughout the Liwan sag basin, suggesting a significant regional erosive process. As the upper limit of U7, the T60 boundary seals most of the structures (faults and dome-shaped structures), presenting locally erosional truncations at the crest of dome 1 (Figure 6b). The faults cutting across U7 and overlying sequences with little displacement may be caused by differential compaction effects after T70.

In all sedimentary units, the depocenters can be clearly defined (Figures 6a' and 6b' and 7a-7g). Controlled by the syndepositional faults, the depocenter of $U 1$ is distributed in the most proximal part. The foresets of the progradation sequences related to the high sediment supply define the depocenter of U2, which is located south of the depocenter of U1. The thickness of U3 varies slightly in the whole sag, with the maximum thickness of over $400 \mathrm{~ms}$ located in the proximal part. However, concerning the sediments of U3 were prominently eroded in the crest of the dome, if the eroded sediments were taken into account, the original maximum thickness of $\mathrm{U} 3$ is inferred to locate in the crest of dome. The thicknesses of U4 and U5 reach their 

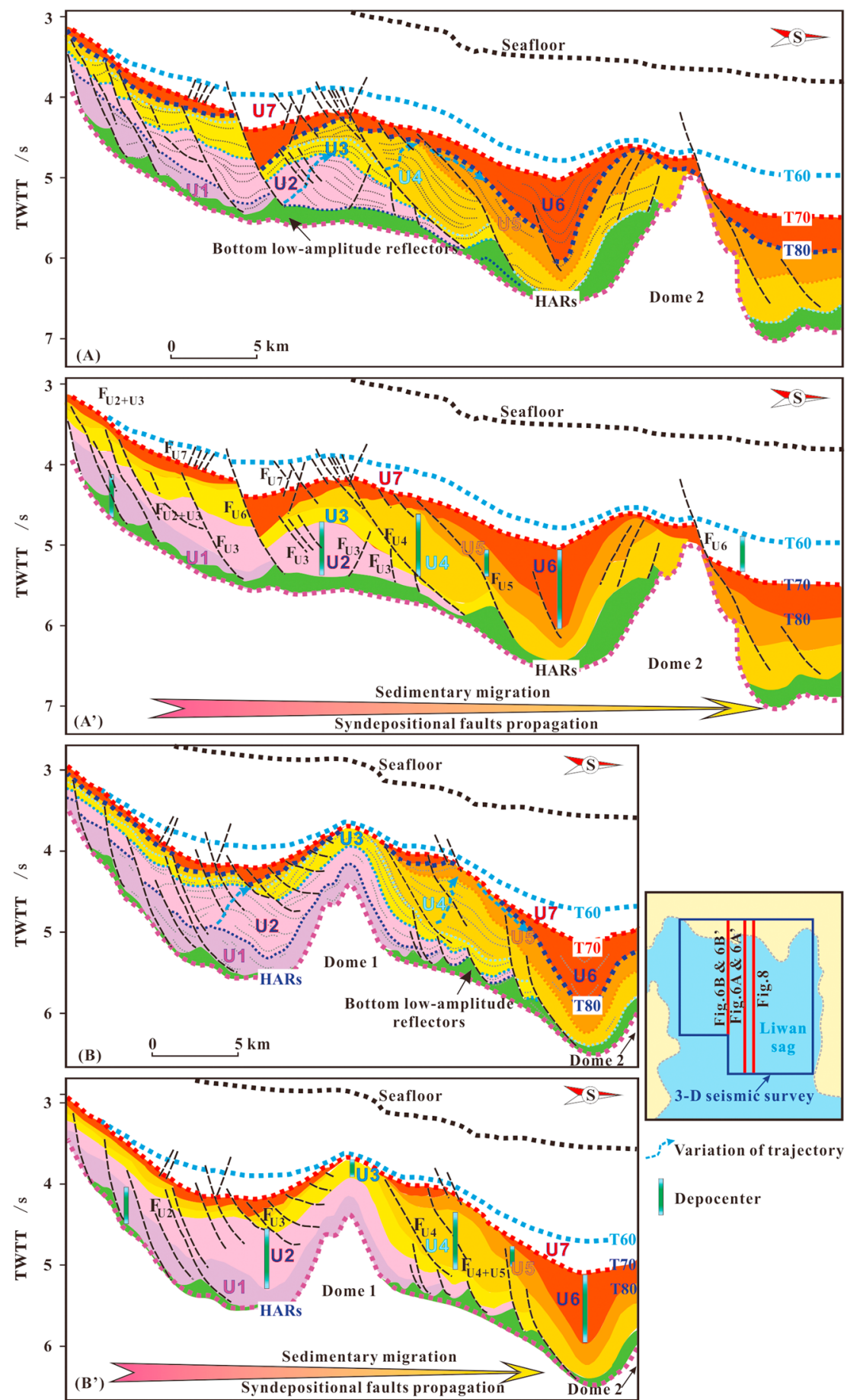

Variation of trajectory

Depocenter

Figure 6. Systematic interpretation of seismic lines for Figures 3 and 4, respectively. (a and b) interpretation showing the stratigraphic framework, erosional unconformities, and inner-unit stacking patterns. Note that T60 seals most of the structures. ( $a^{\prime}$ and $b^{\prime}$ ) Interpretation showing the depocenters of the seven units and the related faults migrating in sequence oceanward.

maximum in the southern limb of the dome, which is enhanced by the normal faults with large offsets developed in the limb. The depocenter of U6 is confined in a synclinal transition zone between two domes. U7 with variable thickness is widespread in the Liwan sag basin, and its depocenter appears at the most distal part, which is affected by normal faults located on the southern limb of the dome. Generally, the depocenters of the seven units exhibit an in-sequence oceanward migration in the Liwan sag basin 

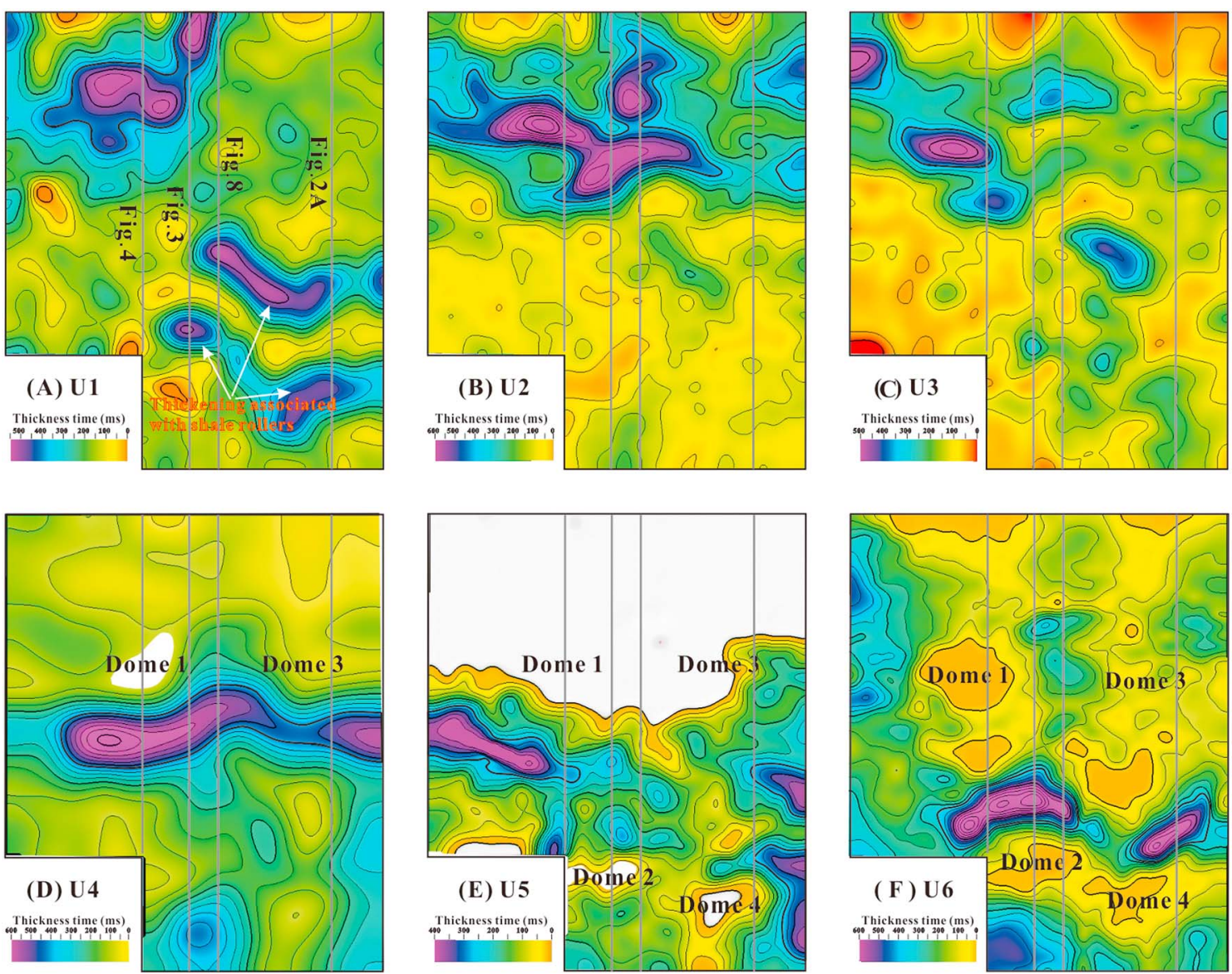

(D) U4

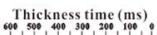

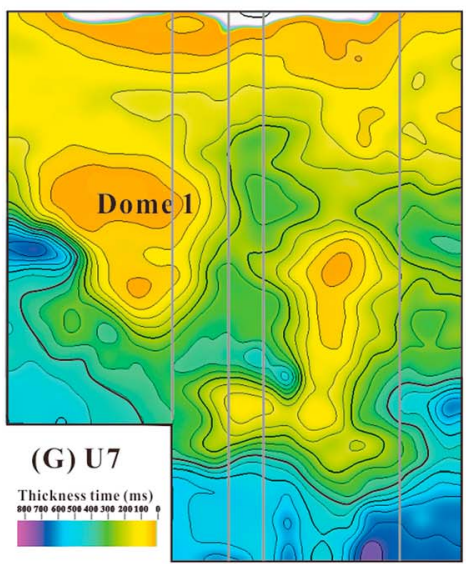

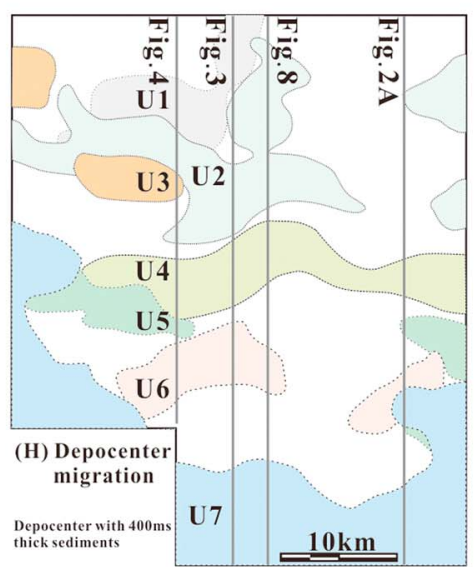

Figure 7. Variation of thickness and migration of depocenters, see Figure 1 for the map location. (a to g) Variation of thickness from U1 to U7. (h) The distribution of over 400-ms-thick sediments showing the southward depocenter migration. The white surfaces correspond to erosional surfaces.

(Figures $6 \mathrm{a}^{\prime}, 6 \mathrm{~b}^{\prime}$, and $7 \mathrm{~h}$ ), in which the basal depocenter with respect to $\mathrm{U} 1$ develops in the proximal part, and the top one with respect to U7 in the most distal part.

\subsubsection{Sediments/Depositional Environments}

Each of the seismic-sedimentary units defined in the previous section coincides with characteristic depositional and erosional architectures corresponding to aggradational, progradational, or regressional systems. Mapping these architectures on the seismic profiles shows lateral and general variations of the stacking patterns, which allows us not only to infer the sediment supply and sedimentary environments but also to discuss potential variations in the accommodation space. 


\subsubsection{Stacking Patterns}

Based on our description, the stacking pattern of each unit is shown in Figure 6. U1 exhibits chaotic to discontinuous internal reflections, downlapping onto the HARs in the distal part. U2 is prominently characterized by a Gilbert-delta facies assemblage, consisting of planar-stratified, flat-lying oceanward dipping topsets, steeply inclined foresets, and tangential bottomsets (e.g., Colella, 1988; Ethridge \& Wescott, 1984; Postma, 1990). U3 generally presents fairly continuous parallel reflectors, which are uplifted and truncated by the T80 and T70 boundaries. Similar to U2, U4 and U5 are marked by progradational sequences. U4 comprises a high-angle, progradational sequence with increasingly sigmoid-shaped progradations oceanward. The overall depositional architecture is controlled by normal faults and nonfilled accommodation space. For instance, the bottom sediments are mounded on the inclined fault plane. However, in U5, only clinoforms dipping oceanward can be observed; the topsets and part of the foresets have been eroded. In general, from U1 to U5, clinoform toes downlap onto the base of each unit. U6 is characterized by an aggradation within a small isolated synclinal region confined by two dome-shaped structures, the sediments downlapped laterally and/or distally. U7 not only exhibits onlapping toward the topographic highs but also shows subhorizontal layering filling and draping farther oceanward, which is similar to the sequences above U7.

The overall observations show that out of the seven units, three (U2, U4, and U5) exhibit an oceanward lateral transition from progradational systems to downlapping geometries. This observation is suggestive of sufficient sediment supply and rapid deposition under shallow marine conditions to the north and deepening of the basin oceanward during individual episodes of progradation. New progradational sequences are always generated in the direction of the future ocean, which is interpreted to reflect the creation of new accommodation space oceanward during the deposition of U1 to U5.

\subsubsection{Lateral Migration of Stacking Patterns}

Herein, we introduce the trajectory concept for further describing the resultant geometries and architectures of sedimentary deposits and for identifying the lateral migration of depositional cycles. The trajectory concept invoked in the study of the shoreline trajectory by Helland-Hansen and Gjelberg (1994) and HellandHansen and Martinsen (1996) has been widely applied to the study of shelf-edge trajectories (e.g., Carvajal \& Steel, 2006; Johannessen \& Steel, 2005; Steel \& Olsen, 2002), in both delta-scale and continental margin-scale clinoforms, both of which are relevant to our study.

Trajectories are typically described from seismic data sets, where vertical stacking patterns and proximal to distal variations in the depositional architecture are well constrained (Figure 8). U2 is characterized by a moderate-angle (Figure 8) ascending trajectory consisting of upward stepping and gently dipping clinoforms. U2 has experienced counterclockwise rotation affected by the related faults; the original trajectory of U2 is thus interpreted as slightly ascending. U4 displays a high-angle (Figure 8) ascending trajectory, which is much closer to the aggradational geometry. This contrasts with the slightly descending trajectory of U5, which is erosionally truncated by the T80 boundary. Trajectory pathways in this margin during the deposition of U1-U5 are progradational in an ascending or descending manner. Internally, the rising trajectories of $U 2$ and $U 4$ consist of upward stepping clinoforms, increasing slope length, and rapid deposition of sediment on the upper slope, which is interpreted to have migrated oceanward during rising accommodation space, whereas the descending trajectory with downward stepping clinoforms implies a slightly falling accommodation space.

\subsubsection{Variation of Paleo-water Depth and Depositional Environments}

The variation of stacking patterns characterized by several inner-unit and intraunit oceanward progradation systems is indicative of the development of the sag infill. Individual progradation systems, defined by topsets, represent shallow-water morphological platforms, while the slope of the clinoforms grades down into deeper water, whereas, the bottomsets represent the deepwater toe to basin-floor areas. In other words, during the deposition of U2-U5, the delivery system changes from topset to foreset to starved basin-floor, indicative of an increase of paleo-water depth from north to south.

Different from the underlying progradational patterns, U6 is marked by a predominantly aggradational system within a small isolated synformal region, reflecting limited accommodation space. Sediments of U7 may be deposited in different sedimentary setting; the draping ones in the proximal part are likely pelagic, whereas the onlapping ones with high amplitude in the distal part are more likely turbidites. U7 is therefore interpreted as a transitional package from an aggradational to a passive infill system. 


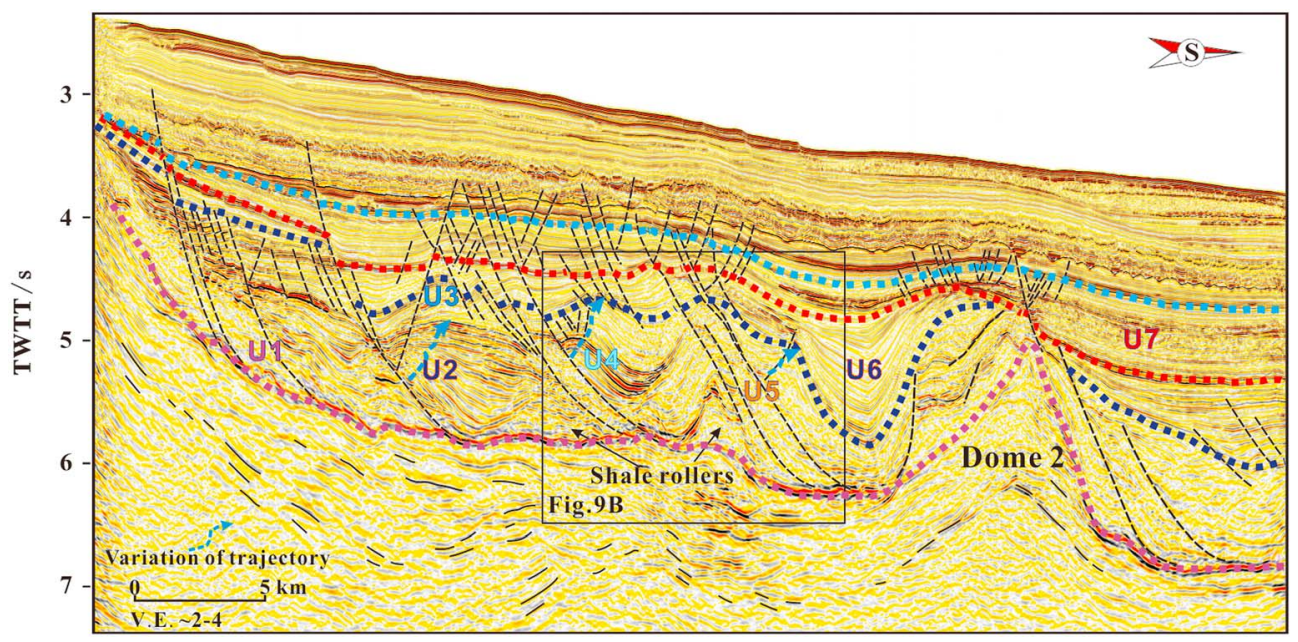

Figure 8. Trajectory pathways showing the variation of inner-unit and intraunit stacking patterns. Note that the tectonic extensional faults sole either onto the HARs or onto the shale. For location see Figure 6.

\subsubsection{Structures}

5.1.3.1. Normal Faults and Shale Rollers (Low-Amplitude Reflectors Overlying HARs)

In the Liwan sag basin, only a few faults are be observed to penetrate at depth into sub-HARs. Most of the faults are small and rooted either into the foresets of different units or the low-amplitude reflectors or HARs. Supra-HARs U1 to U7 present oceanward dipping reflection sequences thickening into the hanging walls of the related faults (if they are not rotated during the formation of the domes). Such growth structures, classically interpreted to form during syndepositional faulting, can be identified in all profiles.

Most syndepositional faults display listric geometries controlling the depocenters. For instance, the related faults of U1, U4, U5, U6, and U7 caused the reflectors to thicken into the related hanging walls where the depocenters are localized (Figures 5 and 6). Furthermore, based on analysis of growth strata, the relative timing of faults can be constrained. In the proximal part, thickening of the sediments toward the hanging wall (Figures 3, 4, and 6) suggests that these faults were active until the deposition of U4. The faults affecting U4 and $\mathrm{U} 5$ formed in sequence in the middle and distal parts. Few faults terminate at T60. Thus, fault activity migrated toward the future ocean, consistent with the migration of the related depocenters. However, the syndepositional faults affecting U6 seem to form out of sequence. These faults can be observed not only in the proximal part (Figures 3 and 4) but also in the aggradational sequences of U6 in the distal part (Figure 3).

We notice the occurrence of low-amplitude reflectors thickening in the footwalls of listric faults. They are markedly asymmetric, show variable thicknesses, and are mainly localized at the bottom of the supraHARs. In the proximal part, low-amplitude reflectors consist of the basal sediments of U1; in the central part, they consist of sediments from U1 and U2; and in the distal part, they comprise sediments of U3. Such lowamplitude reflectors are interpreted as shale rollers (e.g., Ge et al., 1997; Oliveira et al., 2012; Rowan et al., 2012). The sedimentary environment in the Liwan sag basin shows similarities with the Niger delta, with both indicating sufficient sediment supply and rapid deposition under shallow marine conditions during individual episodes of progradation. As a consequence, the shales in the prodelta preserved substantial porosity and pore fluids and became overpressured during loading by the prograding deltas. During this stage, the clays behaved in a macroductile manner and led to the development of shale rollers (e.g., Evamy et al., 1978; Morley, 2003; Nemcok et al., 2005; Rowan et al., 2004). However, most faults sole out either onto the shales or HARs. It is therefore difficult to differentiate between the faults related to tectonic extension and/or to gravity gliding associated with the withdrawal and forward movement of overpressured shales, whereas the deposits of U4 and U5 in the southern limb of the dome could be ascribed to gravity sliding. Shale mobility and shale rollers triggered by overlying deltaic loading could be mostly postdepositional, but unfortunately, it is not possible to constrain the precise timing of the shale rollers in the Liwan sag basin. In the proximal part, the shale rollers comprising shales of $\mathrm{U} 1$ and $\mathrm{U} 2$ are related to the prograding of deltas in U1 and U2. The shale mobility continued with prograding deltas in U4 and U5 and shale rollers 


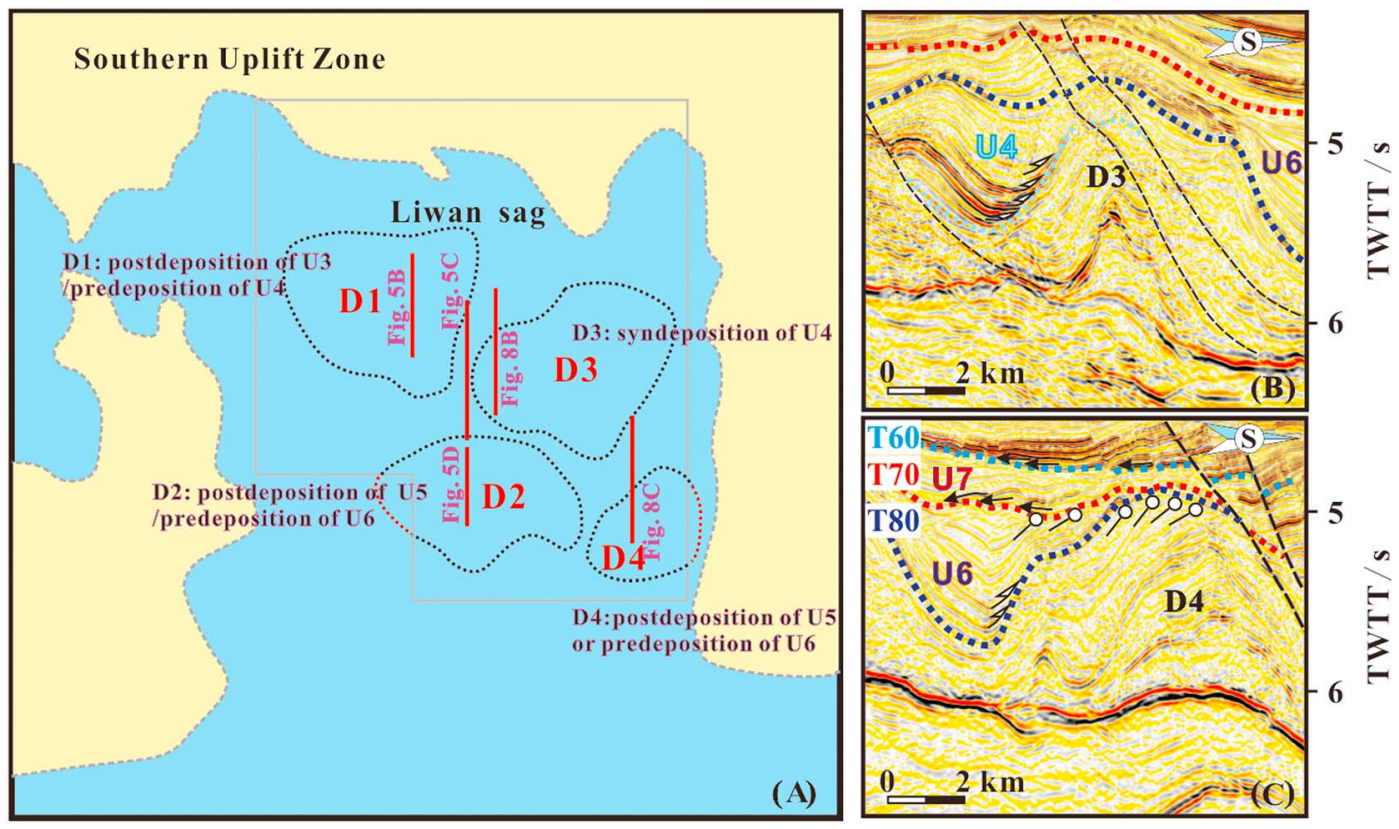

Figure 9. Distribution and timing of the large-scale domes. (a) Distribution of four large-scale domes and the timing of formation. Dome 1 formation postdates deposition of U3 but predates deposition of U4; dome 2 formation postdates deposition of U5 but predates deposition of U6; dome 3 formation occurred during deposition of U4; dome 4 formation postdates deposition of U5 but predates deposition of U6. The domes in the proximal part occurred earlier than those in the distal part. (b) The growth strata associated with dome 3, showing U4 is prominently squeezed up and thinned toward the crest of D3, evidence that D3 grew during deposition of U4. For location see Figure 8. (c) The growth strata associated with the dome 4; note that sediments of U6 onlap toward D4 and get truncated by T70, indicating that D4 grew during deposition of U6. For location see Figure 2a.

developed between the domes, which consist of prodelta shales from U1 to U3. The southern domes seem to serve as barriers to prevent further southward mobility of the shales.

\subsubsection{Dome-Shaped Structures}

5.1.3.2.1. Large-Scale Domes

Four mappable large-scale syndepositional domes have been recognized in the Liwan sag basin (Figure 9). All domes display overall upright axial planes and asymmetric shapes. Most domes are truncated by the unconformity T80 and/or T70 in the crest (Figures 5b, 5d, and 5e) and are overlain by younger sediments downlapping onto the limbs. Such downlapping geometries together with related deformation in U1-U7 indicate the relative timing of the development of the dome-shaped structures discussed in the following paragraphs. In the planar view, all domes are irregular both in shape and in position (Figure 9a). They are referred to as D1, D2, D3, and D4, respectively. The domes show 8- to 20-km wavelength and up to $1.5 \mathrm{~s}$ in height.

\subsection{Timing of Dome-Shaped Structures}

The relative timing of the creation of dome-shaped bodies can be deduced by analyzing the growth strata. Figures 3-5 provide constraints on the timing of D1 and D2 formation. Both U2 and U3 were uplifted by D1, and U3 was truncated by T70. U4 predominantly occurs on the southern limb of D1, with the bottom sediments mounded on the related fault plane. These observations indicate that D1 was generated postdeposition of $\mathrm{U} 3$ or predeposition of $\mathrm{U} 4$, and part of $\mathrm{U} 4$ sediments are probably derived from the eroded $\mathrm{U} 3$ in the crest of D1. The sediments of U7 display onlapping relationships toward the crest of D1, which is truncated by T60 (Figure 5e), indicating that D1 ceased activity at the end of deposition of U7. Oceanward, U6 shows aggradation patterns and laterally onlaps toward the two sides of the topographic high (Figure 5c). D2 therefore is inferred to have grown postdeposition of U5 or predeposition of U6. The deposition of U6 is limited, as a result, in this subbasin and aggrades upward. The sediments of U7 passed D2 and onlapped continuously landward, indicating that D2 ceased activity at $\sim 32 \mathrm{Ma}$, a little earlier than D1. Along the seismic profile (Figure 9b), the typical sigmoidal shape of $\mathrm{U} 4$ changes; the distal $\mathrm{U} 4$ is prominently squeezed up and thinned toward the crest of D3. D3 is thus inferred to have grown syndeposition of U4 and ended activity 
predeposition of U7. The growth strata associated with D4 shows many similarities with what has been observed around D2 (Figure 9c). Sediments of U6 onlapping toward D4 are truncated by T70, indicating that D4 was generated postdeposition of U5 or predeposition of U6.

The interpretation of the syntectonic strata indicates that these dome-shaped structures show remarkable variation in time and space. D1 and D3 in the proximal part were generated earlier than D2 and D4 in the distal part. It is noteworthy that all domes remained active for a long period and cease growth almost coevally at the end of deposition of U6. An exception is D1, which is sealed by the top of U7.

5.1.3.2.3. The Mechanism of Dome-Shaped Structures

The highs in the sub-HARs show similar undulations like the HARs and the overlying large-scale domes (Figures 2-4). We thus consider all domes to be related to deep structures. However, due to limitations in the resolution and the processing of seismic data, the processes that control these structures remain unclear, although timing and the dome-like shapes of these structures favor a magmatic origin. That is to say, such domes mainly correlate with the prebreakup emplacement of magmatic bodies at depth. With the exception of D1, whose growth lasted until the end of deposition of U7, all other domes ceased their activity when breakup occurred, as indicated by the fact that they are sealed by T70, corresponding to the onset of seafloor spreading.

\subsubsection{Decoupling Level (Nature of HARs)}

In the Liwan sag basin, neither the HARs' nature nor their relationship with the underlying crystalline basement is at present understood. Gao et al. (2015) interpreted the undrilled HARs as top crust in their geophysical model. Miao et al. (2013) interpreted the HARs as the base of Cenozoic sediments representing an abrupt change in the sedimentary environment. Zhou et al. (2018) attributed the HARs to detachment faults. However, in terms of our analysis, rare faults with big displacements can be observed cutting across the HARs and penetrating into the sub-HARs. Most normal faults sole out onto the HARs or prodelta shales, so we consider that HARs are a decoupling level, which separates a supra-HAR sequence characterized by extensional deformation and gravity sliding above the shales from the sub-HARs sediments. As for the composition, the HARs at the bottom of the shale layer may be constituted of shales; however, the possibility of magmatic sills cannot be excluded. The sill emplacement may have occurred along the decoupling level in a late stage of the synrift phase, when the HARs were no longer active as a decoupling level.

Because faulting and sedimentation are observed to propagate oceanward, the decoupling is inferred to form under long-term episodic deformation rather than as one single event. The decoupling is therefore diachronous. High sediment supply overlying the mobile overpressured shales, and the tectonic extension responsible for the opening of the SCS may have induced the decoupling along the shales (HARs).

\subsection{Evolution of the Liwan Sag Basin During the Deposition of U1-U7}

Based on seismic observations and correlations within a 3-D seismic data set, we propose a stratigraphic framework, map sediment architectures, syndepositional faults, and domes that enable us to propose a conceptual model of the evolution of the Liwan sag basin during the deposition of U1-U7.

The analysis of the stratigraphic sequences, sedimentary system, and structures demonstrates that the sag basin resulted from a fast sedimentary infill related to a migration of the depocenters toward the future ocean and syndepositional extensional tectonics with gravity sliding (U1 to U3), predominantly decoupling in the supra-HARs. Magmatic addition at depth may have initiated during U4 to U5 and continued during U6 when tectonic extension migrated oceanward. U7 represents early passive infill dominated by compactional deformation with minor tectonic faulting and continuing magmatic addition at depth.

Stage 1: U1 to U3

The sedimentary stacking patterns show vertical and lateral differences during this stage. U2 is prominently characterized by progradational sequences with a slightly ascending trajectory and bottomset, which is typically linked to Gilbert-type deltas (Gilbert, 1885). In general, the proximal part of each unit is interpreted to correspond to shallow marine conditions, which grade to deep water and basin floor conditions in the distal part (Figure 10a). The paleo-water depth increases toward the south. The inner-unit and intraunit oceanward progradation sequences are indicative of high sediment supply during this stage. Small-scale shale rollers can be observed in the proximal part. Deformation during this stage is accommodated by several normal faults in the proximal part. Most faults cutting through the package of U1-U3 are syndepositional and 

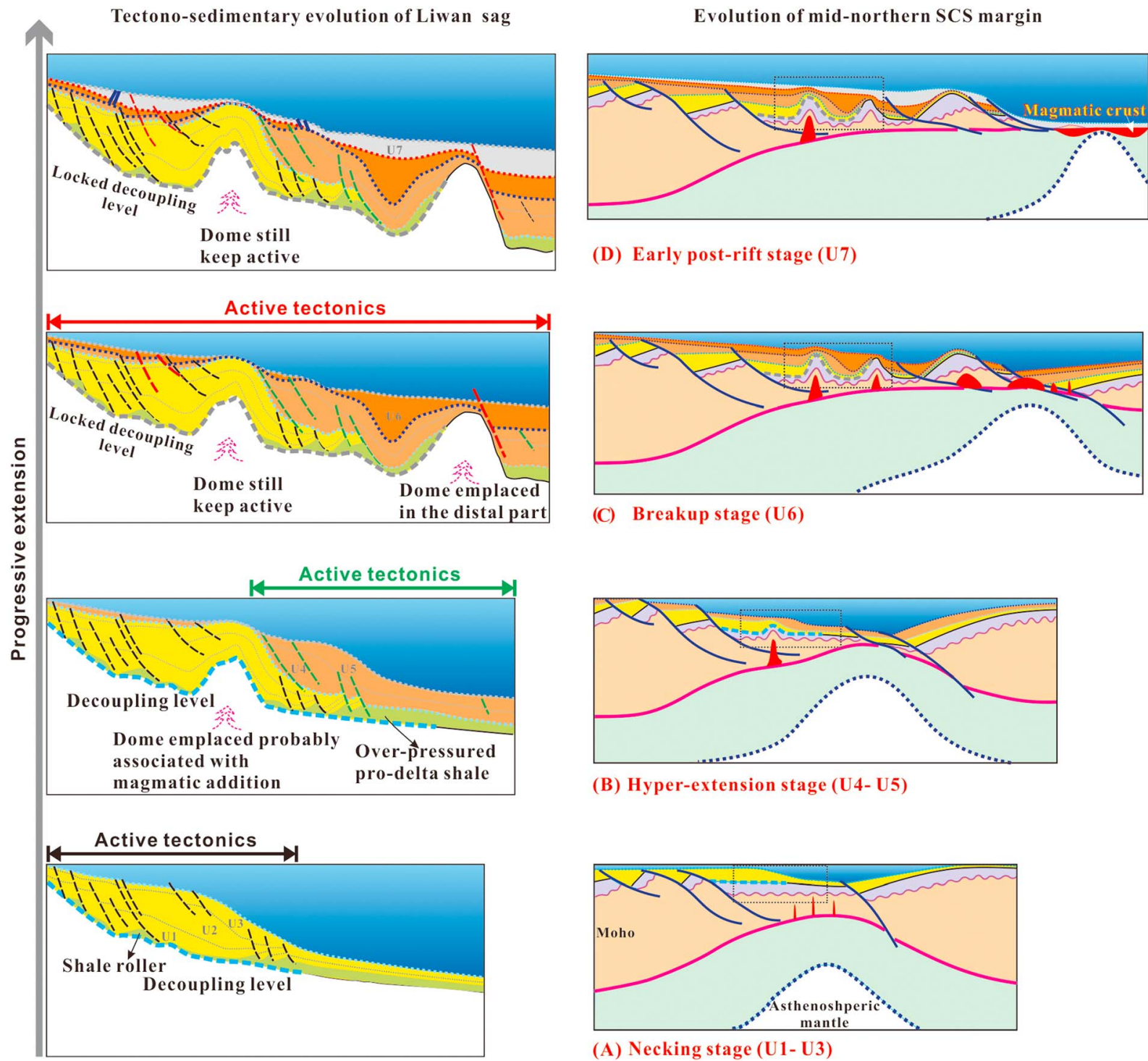

(D) Early post-rift stage (U7)

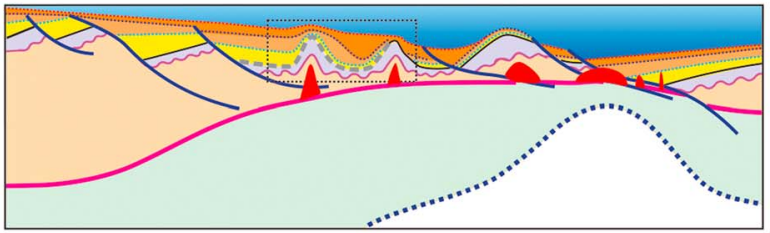

(C) Breakup stage (U6)

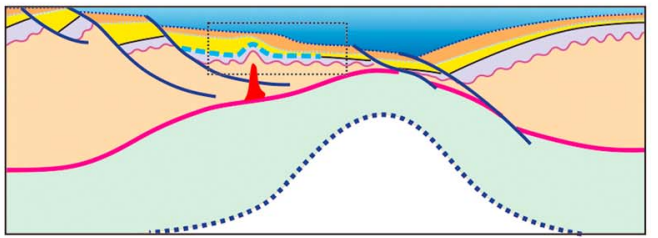

(B) Hyper-extension stage (U4- U5)

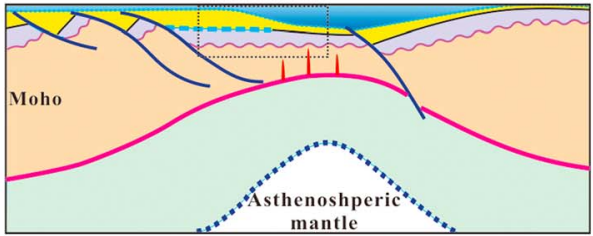

(A) Necking stage (U1 - U3)

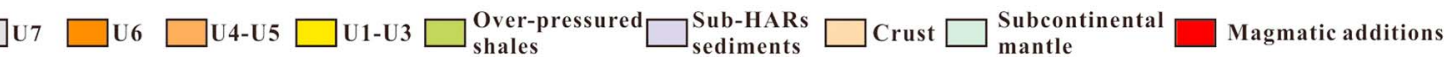

Figure 10. A model interpreting the tectono-sedimentary evolution of the Liwan sag basin (restored from section in Figure 4) and a schematic model of the midnorthern South China Sea (SCS) margin (based on the observation of the Liwan sag) with their main characteristics. (a) Necking stage showing predominantly a progradational system from U1 to U3 and normal faults rooting onto prodelta shales or high-amplitude reflectors (HARs). Decoupling possibly occurred, the crust and upper mantle of the mid northern SCS margin is still necking. (b) Hyperextension stage, the Liwan sag is characterized by sediment progradation. The domes probably associated with magmatic addition emplaced in the proximal part. The faults developing in the southern limb of dome or rooting onto shales are caused by gravity sliding. Extension in the crust and the overlying synrift deposits remained decoupled. At the scale of the margin, the tectonic extension migrated toward the future ocean, contributing to the formation of the hyperextended domain. (c) During breakup stage, minor, small-scale extensional faults continued and were distributed throughout the Liwan sag basin. The domes in the proximal part remained active and in the distal part newly emplaced. The decoupling was locked by the magmatic additions in the distal part. The major tectonic extension at this stage is likely to have migrated outboard and resulted in final breakup. (d) Early postrift stage, minor tectonic extension in the midnorthern margin of the SCS did not stop after breakup. Magmatic addition remained locally active in the sag basin. Tectonic activity completely ceased by the end of this stage.

synrift. However, it is difficult to distinguish between faults related either to tectonic extension or to gravity sliding since both root onto the prodelta shales or the HARs. Because the northern continental margin of the SCS was experiencing tectonic extension, we assume that the decoupling commenced at this stage, but only affected the proximal part (Figure 10a). The stratigraphic architecture of the Gilbert-type deltas has been widely studied, enabling a characterization of the interaction of variation in accommodation space (A) and sediment supply (S; e.g., Garcia-Garcia et al., 2006; Gawthorpe et al., 1994; Rohais et al., 2008). 
According to their results, $\mathrm{U} 2$, showing a progradational system, is subject to a regime of $0<\mathrm{A} / \mathrm{S}<1$. The progradation is due to the existence and/or creation of accommodation space, which in this stage could have been contributed by tectonic subsidence due to crustal thinning. However, there is no direct evidence of crustal thinning. High sediment supply along with creation of increasing accommodation space allowed for a progradation of the depositional system.

Stage 2: U4 to U5

The generation of D1 after the deposition of U3 or prior to the deposition of U4 marks the end of stage 1 and the onset of the creation of deep structures, probably related to magmatic additions at depth (Figure 10b). One major characteristic of stage 2 is intraunit depositional hiatus or erosion. U3 has been eroded in the crest of D1 by T80. The whole U5 is absent in the proximal part, resulting from the truncation of T80. Oceanward, migrating depocenters during the deposition of $\mathrm{U} 4$ and $\mathrm{U} 5$ indicate that the margin remained dominated by sediment progradation with sufficient sediment supply. The emplacement of D1 could have caused U3 sediments to be eroded, reworked, and redeposited in the southern limb of D1 to comprise the progradational sequences in U4. The subsequent sediments bypassed the existing topographic high (D1) and thicken in the distal part. Both U4 and U5 are interpreted as shallow marine deltaic facies. The topset of clinoforms in individual progradation systems associated with deltaic successions are considered to indicate shallow water platform conditions. Southward, they grade into deep water, and the bottomsets represent the deepwater toe to basin-floor areas.

Stage 2 is tectonically marked by the emplacement of D1 and D3 in the proximal part and the shale rollers in the central part. It is notable that the faults along with the oceanward dipping limbs of D1 and D3 root into the foreset and control the depocenters of U4 and U5 (Figure 3), suggesting that they are syndepositional and related to local gravity sliding. Such gravity sliding was induced by the southward progradating sediments of U4 and U5. The shale layer in the distal part became progressively thicker due to the addition of the overlying shales from U2 and U3. At this stage, the Liwan sag basin was affected by tectonic extension; the prominent thinning of the crust to $<10 \mathrm{~km}$ may have occurred at this stage. The emplacement of magmatic additions at depth may have locally interrupted the decoupling in the proximal part, while decoupling and extension continued farther oceanward (Figure 10b), as shown by the fact that no fault penetrated into the sub-HARs.

In this stage, accommodation space was controlled by extension, eustasy, regional isostatic adjustment, and gravity sliding. Ascending trajectories in U4 imply an increasing accommodation space. This accommodation space was most likely generated by eustasy superimposed on regional isostatic adjustment. However, the sediment supply greatly outpaced the creation of the accommodation space, as indicated by the strong progradation. In contrast, U5 implies a setting with slight falling accommodation space. The appearance of erosional unconformities on top of $\mathrm{U} 4$ and $\mathrm{U} 5$ shows that the systems are prograding with $\mathrm{A} / \mathrm{S}<0$ predeposition of U6, which was probably caused by a combination of uplift driven by magmatic addition, and high sediment input controlled by the progradation of the deltaic fan in a shallow marine environment.

Stage 3: U6

Stage 3 is tectonically marked by deep structures at depth with tectonic extension. In this stage, D1 and D3 remain active, while D2 and D4 initiated growth in a more distal position after deposition of U5 (Figure 10c). The syndepositional faults found in the proximal part, in the crest of some domes, and in the distal part are interpreted to occur under tectonic extension. This interpretation means that the tectonic extension is backstepping or widening. Most structures (faults, shale rollers, and dome-shaped structures) in the Liwan sag basin ceased major deformation coevally prior to deposition of U7. We can therefore conclude that active tectonic extension and magmatic addition reached a climax during the deposition of U6. The decoupling was invoked to explain crust thinning in the absence of faults that cut across and thin the crust. The decoupling was locked in the distal part of the Liwan sag basin, probably by the emplacement of magmatic bodies (e.g., D2 and D4; Figure 10c). The aggradation system of U6 suggests that topographic highs associated with D2 served as barriers to prevent the oceanward transport of the sediments and controlled the observed aggradation. The aggradation system of U6 reflects a setting with limited accommodation, which was most likely created by a combination of eustasy, background isostatic adjustment, and, most important, ongoing magmatism at depth and tectonic extension in the frontal part. 
Stage 4: U7

The whole Liwan sag basin entered the postrift stage postdating the opening of the SCS. Most structures ceased to be active prior to the deposition of U7. Some small-scale faults with little displacement may have been caused by differential compaction. A few normal faults controlling local sediment thickening can be observed as well (Figure 10d). But it is difficult to distinguish between differential compaction and minor tectonic faulting. D1 remained active at this stage, indicating that the process related to its formation, which is most likely magmatic addition, continued even after the opening of the SCS. Deformation attenuated gradually and ceased during the deposition of U7, followed by subsequent quiescence postdeposition of U7. Thermal equilibration and related subsidence became the dominant control of the increased accommodation space.

\subsection{Evolution of the Liwan Sag Basin Prior to the Deposition of U1}

The well-laminated reflectors below the HARs, as well as those coring the domes, are considered to represent sediments. The detailed structures in the sub-HARs cannot be defined due to the resolution or processing of the seismic data. The highs in the sub-HARs, most likely produced by magmatic additions, are only roughly imaged; however, they affect the overlying sediments.

The sediments marked by well-layered reflectors in the sub-HARs can be observed as deep as $7 \mathrm{~s}$ (TWTT; e.g., Figure 2). The Moho depth is at more than $9.6 \mathrm{~s}$ (TWTT). According to the function of time-depth conversions proposed by Zhou et al. (2008), the top basement and Moho correspond to a depth of 13.2 and $20.1 \mathrm{~km}$, respectively. So the crustal thickness is generally no more than $7 \mathrm{~km}$ in the Liwan sag basin. Following the definition of hyperextension, which is defined as a crust thinned to less than $10 \mathrm{~km}$ (Sutra et al., 2013), the Liwan sag basin can be classified as hyperextended. The complete decoupling between the suprashale and subshales may occur during hyperextension. Moreover, the structures responsible for the crustal thinning must only exist below the decoupling level.

\subsection{Evolution of the Liwan Sag Basin as Part of the Midnorthern SCS Margin}

Following our observations, we interpret the predominantly oceanward inclined HARs as a decoupling level, which continued to form through the development of tectonic extension, gravity sliding, and most likely also magmatic additions. Decoupling initiated during the deposition of U1 and ended first in the proximal part (syn-U4?) and then in the distal part (syn-U6) with the emplacement of the domes (D1 to D4). Extensional faulting migrated oceanward as indicated by late faults in the $\mathrm{OMH}$. The migration of extension outboard is a key result of this paper. Unconformity T70 marks the transition from tectonic extension to postrift thermal isostatic equilibration. Minor tectonic extension and addition of magma still continued during deposition of U7 but finally ceased by the end of deposition of U7.

Our interpretation allows us to link our observations in the Liwan sag basin with first-order tectonic processes that controlled the evolution of the midnorthern SCS margin, that is, crustal thinning (tectonic extension/decoupling/Moho structure) and related subsidence history and creation of accommodation space. Moreover, we discuss the possibility of magmatic additions at depth and their effect on the supraHAR infill history as a function of the evolution of the margin. Combined with the syndepositional evolution of U1 to U7, we propose a conceptual model that describes the evolution of the distal midnorthern SCS margin in four stages.

5.4.1. Necking Stage (U1 to U3)

The deformation and the state of the crust/lithosphere prior to the deposition of U1 are little constrained. The midnorthern continental margin of the SCS underwent significant tectonic extension during deposition of U1 to U3. Normal faults developed in the proximal part of Liwan sag basin that sole onto the shales or HARs. The mechanism controlling these faults is uncertain; it could be either tectonic or gravity sliding. However, because no faults penetrated into the crust, the deformation in the supra-HARs made little contribution on the crustal and upper mantle necking in the Liwan sag basin. Thus, the intense extensional deformation in the crust and upper mantle during necking, that is, during rapid thinning of the crust, to $<10 \mathrm{~km}$ had to be almost completely decoupled along the prodelta shales and the HARs in the Liwan sag basin (Figure 10a). The only direct evidence for crustal thinning in the supra-HARs is the oceanward increase in total accommodation space (e.g., Sutra \& Manatschal, 2012). We consider that the shale-dominated sequence overlying the HARs was deposited during decoupling and helped to keep the decoupling level 
efficient. The depositional architecture over the thinning crust shows that the proximal part of the basin was filled to the top (sediment supply $\geq$ creation of accommodation space) as indicated by the occurrence of Gilbert deltaic successions in U2 and progradation systems from U1 to U3. The loading of rapidly prograding deltas caused the flowage and expulsion of overpressured shales to form the shale rollers along active normal faults soling into the shales. The simultaneous tectonic extension may have migrated farther outboard creating an underfilled basin over an actively thinning crust/lithosphere.

\subsubsection{Hyperextension Stage (U4 to U5)}

Decoupling with gravity sliding along the shales predominantly controlled the main synrift sequences in the Liwan sag basin. The syndepositional deformation migrated oceanward together with the related depocenters. Both tectonic and gravity-sliding faults occurred in the central basin, migrating southward compared to the necking stage. No faults cut through the sub-HARs, suggesting that extension in the crust and the overlying synrift deposits remained decoupled (Figure 10b). The possible occurrence of magmatic additions at depth may explain the formation of D1 and D3. Such magmatic additions formed as a consequence of the rising asthenosphere. The continuation of progradational deltaic sequences (U4 and U5) and high sediment supply indicates that the proximal Liwan sag basin remained mainly in shallow marine conditions. In contrast, in the distal parts, the synextensional thermal equilibration may have caused an underfilled domain. The preexisting shale layer in the central part was induced to initiate flowage under the loading of progradational deltaic systems, resulting in the development of shale rollers below the fault blocks.

\subsubsection{Breakup Stage (U6)}

The midnorthern SCS margin experienced its last stage of tectonic extension during deposition of U6. D1 and D3 remained active, while new domes (e.g., D2 and D4), most likely associated with magmatic additions, initiated in the distal margin, indicating that the main tectonic structures had migrated southward, while minor, small-scale extensional faults continued and were distributed throughout the synrift infill of the Liwan sag basin. The major tectonic extension is likely to have migrated outboard at this stage and contributed to the formation of a hyperextended domain outboard (Figure 10c), as evidenced by the faults penetrating into the crust underneath the $\mathrm{OMH}$. In other words, the decoupling, locked by the magmatic additions (D1 to D4), had to occur simultaneously with migration of extension in the distal part, resulting in the final breakup. The sequential migration of deformation is reflected in the diachronous sedimentary sequences that young toward the future distal margin. However, the topographic highs associated with D2 and D4 may have served as barriers to prevent the oceanward transport of the sediments and controlled the observed aggradation in U6 in a limited accommodation setting.

\subsubsection{Early Postrift Stage (U7)}

The Liwan sag basin eventually became part of the distal midnorthern SCS margin, and the sag basin was subjected to thermal subsidence. The faults affecting U7 were mostly produced by differential compaction. However, minor tectonic extension in the midnorthern margin of the SCS did not stop after breakup and during formation of first oceanic crust at around $30 \mathrm{Ma}$. Tectonic activity completely ceased by the time T60 was formed. Magmatic addition remained locally active in the sag basin and migrated outboard during this stage and may have affected the OMH (Figure 10d). The sedimentary system shifted during the deposition of U7 to a typical passive infill mode.

\section{Conclusions}

The aim of our study was to investigate, using a 3-D seismic survey, how the tectonic extension and sedimentary infill evolved in time and space in the Liwan sag basin located in the midnorthern continental margin of the SCS. Major outcomes of this study are that (1) tectonic extension and the related depositional systems migrated oceanward and (2) the synrift deformation in the basement is decoupled along prodelta shale layers from deformation in the synrift sedimentary sequence. These observations suggest a diachronous oceanward younging of the sedimentary and deformation processes. The decoupling between basement and the overlying synrift sequence explains the lack of classical synrift wedges and that the overall architecture of the synrift sedimentary sequence looks little deformed.

On the basis of seismic interpretation, we propose a new model for the evolution of the Liwan sag basin. In this model, the decoupling developed during the deposition of U1-U5. The oceanward dipping HARs and prodelta shale layers are demonstrated to act as a basal decoupling level between a strongly thinning crust/lithosphere and a thick synrift sedimentary sequence. Late extensional dome-like structures, 
probably related to magmatic additions, affected both the decoupling level (HARs) and the synrift infill. During the last stage of tectonic extension, the thinning of the lithosphere reached a climax, reflected by an oceanward increase of magmatic addition at depth that is linked to major lithospheric thinning.

High-resolution 3-D seismic data of the Liwan sag basin enabled us to understand the tectono-sedimentary evolution and to propose a coherent evolution of the distal midnorthern SCS margin. We believe that these results will help to better understand rifted margins along which extension in the crust is decoupled from extension in the synrift sedimentary sequence leading to so called sag basins.

\section{Acknowledgments}

Seismic lines used for this study have been provided by the Shenzhen Branch of China National Offshore Oil Corporation (CNOOC) after personal request and are published with the permission of CNOOC. This paper benefited from the constructive reviews of Jean-Claude Ringenbach and an anonymous reviewer and additional comments from Editor Luc L. Lavier. We are grateful to Haiteng Zhuo for fruitful discussions. This study was financially supported by the joint foundation of NSFC and Guangdong province (U1301233), Key Program of NSFC (41730532), Science and Technology Program of Guangzhou (201804010371), Guangdong Natural Science Foundation research team project (2017A030312002), and National Science and Technology Major Project (2011ZX05025-003-005). The data used for this study are available as listed in the references or as provided in the supporting information.

\section{References}

Briais, A., Patriat, P., \& Tapponnier, P. (1993). Updated interpretation of magnetic anomalies and seafloor spreading stages in the South China Sea: Implication for the tertiary tectonics of Southeast Asia. Journal of Geophysical Research, 98(B4), 6299-6328. https://doi.org/ 10.1029/92JB02280

Carvajal, C. R., \& Steel, R. J. (2006). Thick turbidite successions from supply-dominated shelves during sea-level highstand. Geology, 34(8), 665-668. https://doi.org/10.1130/G22505.1

Colella, A. (1988). Pliocene-Holocene fan deltas and braid deltas in the Crati Basin, southern Italy: A consequence of varying tectonic conditions. In W. Nemec, \& R. J. Steel (Eds.), Fan deltas: Sedimentology and tectonic setting (pp. 50-74) London: Blackie.

Deptuck, M. E., Kendell, K., \& Smith, P. (2009). Complex deepwater fold-belts in the SW sable subbasin, offshore Nova Scotia. In Frontiers Innovation (p. 4). Calgary, Alberta Canada: CSPG CSEG CWLS Convention.

Duval, B., Cramez, C., \& Jackson, M. P. A. (1992). Raft tectonics in the Kwanza Basin, Angola. Marine and Petroleum Geology, 9(4), 389-404 . https://doi.org/10.1016/0264-8172(92)90050-O

Espurt, N., Callot, J.-P., Totterdell, J., Struckmeyer, H., \& Vially, R. (2009). Interactions between continental breakup dynamics and largescale delta system evolution: Insights from the cretaceous Ceduna delta system, bight basin, southern Australian margin. Tectonics, 28, TC6002. https://doi.org/10.1029/2009TC002447

Ethridge, F., \& Wescott, W. (1984). Tectonic setting, recognition and hydrocarbon potential of fan-delta deposits. Canadian Society of Petroleum Geologists Memoir, 10, 217-236.

Evamy, B. D., Karemboure, J., Kamerling, P., Knaap, W. A., Molloy, F. A., \& Rowlands, P. H. (1978). Hydrocarbon habitat of tertiary Niger delta. AAPG Bulletin, 62, 1-39.

Gao, J., Wu, S., McIntosh, K., Mi, L., Yao, B., Chen, Z., \& Jia, L. (2015). The continent-ocean transition at the mid-northern margin of the South China Sea. Tectonophysics, 654, 1-19. https://doi.org/10.1016/j.tecto.2015.03.003

Garcia-Garcia, F., Fernandez, J., Viseras, C., \& Soria, J. M. (2006). Architecture and sedimentary facies evolution in a delta stack controlled by fault growth (Betic, southern Spain, late Tortonian). Sedimentary Geology, 185(1-2), 79-92. https://doi.org/10.1016/j. sedgeo.2005.10.010

Gawthorpe, R., Fraser, A., \& Collier, R. (1994). Sequence stratigraphy in active extensional basins: Implications for the interpretation of ancient basin fills. Marine and Petroleum Geology, 11, 642-658.

Ge, H., Jackson, M. P. A., \& Vendeville, B. C. (1997). Kinematics and dynamics of salt tectonics driven by progradation. AAPG Bulletin, 81 , 398-423.

Gilbert, G. K. (1885). The topographic features of lake shores. US geological survey Annual Report, 5, 69-123.

Gillard, M., Autin, J., Manatschal, G., Sauter, D., Munschy, M., \& Schaming, M. (2015). Tectonomagmatic evolution of the final stages of rifting along the deep conjugate Australian-Antarctic magma-poor rifted margins: Constraints from seismic observations. Tectonics, 34, 753-783. https://doi.org/10.1002/2015TC003850

Helland-Hansen, W., \& Gjelberg, J. G. (1994). Conceptual basis and variability in sequence stratigraphy: A different perspective. Sedimentary Geology, 92(1-2), 31-52. https://doi.org/10.1016/0037-0738(94)90053-1

Helland-Hansen, W., \& Martinsen, O. J. (1996). Shoreline trajectories and sequences: Description of variable depositional-dip scenarios. Journal of Sedimentary Research, 66(4), 670-688.

Hinz, K., \& Schlüter, H. U. (1985). Geology of the dangerous grounds, South China Sea, and the continental margin off Southwest Palawan Results of Sonne cruises SO-23 and SO-27. Energy, 10, 282-288.

Holloway, N. (1982). North Palawan block, Philippines; its relation to Asian mainland and role in evolution of South China Sea. $A A P G$ Bulletin, 66, 1355-1383.

Huang, C. J., Zhou, D., Sun, Z., Chen, C. M., \& Hao, H. J. (2005). Deep crustal structure of Baiyun sag, northern South China Sea revealed fromdeep seismic reflection profile. Chinese Science Bulletin (in Chinese), 50(11), 1131-1138. https://doi.org/10.1360/04wd0207

Hudec, M. R., \& Jackson, M. P. A. (2004). Regional restoration across the Kwanza Basin, Anglola: Salt tectonics triggered by repeated uplift of a metastable passive margin. AAPG Bulletin, 88(7), 971-990. https://doi.org/10.1306/02050403061

Huismans, R., \& Beaumont, C. (2011). Depth-dependent extension, two-stage breakup and cratonic underplating at rifted margins. Nature, 473(7345), 74-78. https://doi.org/10.1038/nature09988

Ings, S. J., \& Shimeld, J. W. (2006). A new conceptual model for the structural evolution of a regional salt detachment on the northeast Scotian margin, offshore eastern Canada. AAPG Bulletin, 90(9), 1407-1423. https://doi.org/10.1306/04050605159

Jammes, S., Manatschal, G., \& Lavier, L. (2010). Interaction between prerift salt and detachment faulting in hyperextended rift systems: The example of the parentis and Mauléon basins (Bay of Biscay and western Pyrenees). AAPG Bulletin, 94(7), 957-975. https://doi.org/ $10.1306 / 12090909116$

Ji, M., Zhang, G., Zhao, Z., Yang, C., \& Zeng, Q. (2014). The tectonic evolution of Liwan sag in the deep-water area of the South China Sea and its oil geological significance. Geological Bulletin of China (in Chinese), 33(5), 723-732.

Jian, Z., Larsen, H.C., Alvarez Zarikian, C.A. \& the Expedition 367/368 Scientists (2018). Site U1505. In Z., Sun, Z., Jian, J.M., Stock \& the Expedition 367/368 Scientists (Eds.), South China Sea Rifted Margin. Proc. IODP, Vol. 367/368, Ch. 9.

Johannessen, E. P., \& Steel, R. J. (2005). Shelf-margin clinoforms and prediction of Deepwater sands. Basin Research, 17(4), 521-550. https://doi.org/10.1111/j.1365-2117.2005.00278.x

Larsen, H.C., Jian, Z., Alvarez Zarikian, C.A. \& the Expedition 367/368 Scientists (2018a). Site U1501. In Z., Sun, Z., Jian, J.M., Stock \& the Expedition 367/368 Scientists (Eds.), South China Sea Rifted Margin. Proc. IODP, Vol. 367/368, Ch. 5. 
Larsen, H. C., Mohn, G., Nirrengarten, M., \& Expedition 367 and 368 Scientists (2018b). Rapid transition from continental breakup to igneous oceanic crust in the South China Sea. Nature Geoscience, 11(10), 782-789. https://doi.org/10.1038/s41561-018-0198-1

Liao, J., Xu, Q., Chen, Y., Wang, Y., Cai, L., Zou, M., et al. (2016). Sedimentary characteristics and genesis of the Deepwater channel system in Zhujiang formation of Baiyun-Liwan sag. Earth Science (in Chinese), 41(6), 1041-1054. https://doi.org/10.3799/dqkx.2016.086

Lister, G. S., Etheridge, M. A., \& Symonds, P. A. (1991). Detachment models for the formation of passive continental margins. Tectonics, 10(5), 1038-1064. https://doi.org/10.1029/90TC01007

Liu, S., Zhang, C., Sun, Z., Pang, X., Shen, J., \& Qiu, N. (2016). Characteristics and significances of the geological boundary SB21 in the Zhujiang formation of the Liwan sag, Pearl River Mouth Basin. Earth Science (in Chinese), 41(3), 47 5-4 7 486. https://doi.org/10.3799/ dqkx.2016.039

Miao, S., Zhang, G., Liang, J., Yang, H., Ji, M., Shen, H., \& Chen, Y. (2013). Delta depositional system and source rock characteristics of Enping formation, Liwan sag in ultra deep-water area of northern South China Sea. Acta Petrolei Sinica (in Chinese), 34, 57-65. https:// doi.org/10.7623/syxb2013S2007

Morley, C. K. (2003). Mobile shale related deformation in large deltas developed on passive and active margins. In P. Van Rensbergen, R. R. Hillis, A. J. Maltman, \& C. K. Morley (Eds.), Subsurface sediment mobilization. Geological Society of London, Special Publications, 216, 335-357. https://doi.org/10.1144/GSL.SP.2003.216.01.22

Morley, C. K., King, R., Hillis, R., Tingay, M., \& Backe, G. (2011). Deepwater fold and thrust belt classification, tectonics, structure and hydrocarbon prospectivity: A review. Earth-Science Reviews, 104(1-3), 41-91. https://doi.org/10.1016/j.earscirev.2010.09.010

Nemcok, M., Schamel, S., \& Gayer, R. (2005). Thrust belts: Structural architecture, thermal regimes, and petroleum systems, (p. 541). Cambridge: Cambridge University Press. https://doi.org/10.1017/CBO9780511584244

Oliveira, M. J. R., Zalán, P. V., Caldeira, J. L., Tanaka, A., Santarem, P., Ivo, T. Jr., \& Moraes, A. (2012). Linked extensional-compressional tectonics in gravitational systems in the equatorial margin of Brazil. In D. Gao (Ed.), Tectonics and sedimentationImplications for petroleum systems, AAPG Memoir (Vol. 100, pp. 159-178). Tulsa.

Osmundsen, P. T., \& Ebbing, J. (2008). Styles of extension offshore mid-Norway and implications for mechanisms of crustal thinning at passive margins. Tectonics, 27, TC6016. https://doi.org/10.1029/2007TC002242

Pang, X., Chen, C., Peng, D., Zhou, D., \& Chen, H. (2007). The Pearl River deep-water fan system \& petroleum in South China Sea, (1st ed. p. 156). Beijing: Science press.

Patriat, P. (1987). Reconstitution de l'évolution du systéme de dorsales de l'Océan Indien par les méthodes de la cinématique des plaques, Territoire des Terres Australes et Antarctique Françcaises (p. 308). PhD Thesis, Université de Paris VI, France.

Peel, E. J., Hossack, J. R., \& Travis, C. J. (1995). Genetic structural provinces and salt tectonics of the Cenozoic offshore U.S. Gulf of Mexico: A preliminary analysis. In M. P. A. Jackson, D. G. Roberts, \& S. Snelson (Eds.), Salt tectonics: A global perspective, AAPG Memoir (Vol. 65, pp. 153-175). Tulsa.

Péron-Pinvidic, G., Manatschal, G., Minshull, T. A., \& Sawyer, D. S. (2007). Tectonosedimentary evolution of the deep IberiaNewfoundland margins: Evidence for a complex breakup history. Tectonics, 26, TC2011. https://doi.org/10.1029/2006TC001970

Postma, G. (1990). Depositional architectures and facies of river and fan deltas: A synthesis. In A. Colella, \& D. B. Prior (Eds.), Coarse Grained Deltas, IAS Special Publication (Vol. 10, pp. 13-27). Oxford: Blackwell Publishing Ltd.

Reston, T. J., \& McDermott, K. G. (2011). Successive detachment faults and mantle unroofing at magma-poor rifted margins. Geology, 39(11), 1071-1074. https://doi.org/10.1130/G32428.1

Rohais, S., Eschard, R., \& Guillocheau, F. (2008). Depositional model and stratigraphic architecture of rift climax Gilbert-type fan deltas (gulf of Corinth, Greece). Sedimentary Geology, 210(3-4), 132-145. https://doi.org/10.1016/j.sedgeo.2008.08.001

Rowan, M. G., Peel, F. J., \& Vendeville, B. C. (2004). Gravity-driven fold belts on passive margins. In K. R. McClay (Ed.), Thrust tectonics and hydrocarbon systems, AAPG Memoir (Vol. 82, pp. 157-182). Tulsa.

Rowan, M. G., Peel, F. J., Vendeville, B. C., \& Gaullier, V. (2012). Salt tectonics at passive margins: Geology versus models-Discussion. Marine and Petroleum Geology, 37(1), 184-194. https://doi.org/10.1016/j.marpetgeo.2012.04.007

Ru, K., \& Pigott, J. D. (1986). Episodic rifting and subsidence in the South China Sea. AAPG Bulletin, 70, 1136-1155.

Spathopoulos, F. (1996). An insight on salt tectonics in the Angola Basin, South Atlantic. In G. I. Alsop, D. J. Blundell, I. Davison (Eds.), Salt tectonics. Geological Society of London Specical Publication, 100, 153-174. https://doi.org/10.1144/GSL.SP.1996.100.01.11

Steel, R. J., \& Olsen, T. (2002). Clinoforms, clinoform trajectories and deepwater sands. In J. M. Armentrout, \& N. C. Rosen (Eds.), Sequence stratigraphic models for exploration and production: Evolving methodology, emerging models and application histories, Special Publication GCS-SEPM (pp. 367-381). Houston, TX.

Sutra, E., \& Manatschal, G. (2012). How does the continental crust thin in a hyperextended rifted margin? Insights from the Iberia margin Geology, 40(2), 139-142. https://doi.org/10.1130/G32786.1

Sutra, E., Manatschal, G., Mohn, G., \& Unternehr, P. (2013). Quantification and restoration of extensional deformation along the Western Iberia and Newfoundland rifted margins. Geochemistry, Geophysics, Geosystems, 14, 2575-2597. https://doi.org/10.1002/ggge.20135

Tari, G., Molnar, J., \& Ashton, P. (2003). Examples of salt tectonics from West Africa: A comparative approach. In P. Doyle, F. J. Gregory, J. S. Griffiths, A. J. Hartley, R. E. Holdsworth, A. C. Morton, N. S. Robins, M. S. Stocker, \& J. P. Turner (Eds.), Petroleum geology of Africa: New themes and developing technologies. Geological Society of London, Special Publication, 207, 85-104.

Taylor, B., \& Hayes, D. E. (1983). Origin and history of the South China Sea basin. Geophysical Monograph Series, 27, 23-56.

Wade, J. A., \& MacLean, B. C. (1990). The geology of the southeastern margin of Canada. In M. J. Keen, \& G. L. Williams (Eds.), Geology of the continental margin of eastern Canada. Geological Survey of Canada, 2, 167-238.

Whitmarsh, R. B., Manatschal, G., \& Minshull, T. A. (2001). Evolution of magma-poor continental margins from rifting to seafloor spreading. Nature, 413(6852), 150-154. https://doi.org/10.1038/35093085

Xie, H., Di, Z., Li, Y., Pang, X., Li, P., Chen, G., et al. (2014). Cenozoic tectonic subsidence in Deepwater sags in the Pearl River MouthnBasin, northern South China Sea. Tectonophysics, 615-616, 182-198. https://doi.org/10.1016/j.tecto.2014.01.010

Yan, P., Zhou, D., \& Liu, Z. (2001). A crustal structure profile across the northern continental margin of the South China Sea. Tectonophysics, 338, 1-21.

Zhou, D., Hu, D., He, M., \& Lian, S. Y. (2008). The selection of fitting curve in time-depth transformation of deep-seated strata and crust. Earth Science (in Chinese), 33, 531-537.

Zhou, D., Wang, W., Pang, X., Wang, J., Cai, D., \& Sun, Z. (2006). Mesozoic subduction- accretion zone in northwastern South China Sea inferred from geophysical interpretations. Science in China (Series D) (in Chinese), 36(3), 209-218.

Zhou, Z., Mei, L., Liu, J., Zheng, J., Chen, L., \& Hao, S. (2018). Continentward-dipping detachment fault system and asymmetric rift structure of the Baiyun sag, northern South China Sea. Tectonophysics, 726, 121-136. https://doi.org/10.1016/j.tecto.2018.02.002 